\title{
Online Live-Stream Broadcasting of the Holy Mass during the COVID-19 Pandemic in Poland as an Example of the Mediatisation of Religion: Empirical Studies in the Field of Mass Media Studies and Pastoral Theology
}

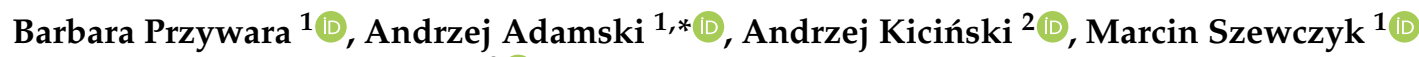 \\ and Anna Jupowicz-Ginalska ${ }^{3}$ (D) \\ check for \\ updates \\ Citation: Przywara, Barbara, \\ Andrzej Adamski, Andrzej Kiciński, \\ Marcin Szewczyk, and Anna \\ 1 College of Media and Social Communication, University of Information Technology and Management in \\ Rzeszow, ul. Sucharskiego 2, 35-225 Rzeszow, Poland; bprzywara@wsiz.edu.pl (B.P.); \\ mszewczyk@wsiz.edu.pl (M.S.) \\ 2 The Faculty of Theology, John Paul II Catholic University of Lublin, al. Racławickie 14, 20-950 Lublin, Poland \\ andrzej.kicinski@kul.pl \\ 3 The Faculty of Journalism, Information and Book Studies, University of Warsaw, ul. Bednarska 2/4, \\ 00-310 Warsaw, Poland; a.ginalska@uw.edu.pl \\ * Correspondence: aadamski@wsiz.edu.pl
} Jupowicz-Ginalska. 2021. Online Live-Stream Broadcasting of the Holy Mass during the COVID-19 Pandemic in Poland as an Example of the Mediatisation of Religion: Empirical Studies in the Field of Mass Media Studies and Pastoral Theology. Religions 12: 261. https://doi.org/ $10.3390 /$ rel12040261

Academic Editors: Enzo Pace and Antonio Muñoz-García

Received: 4 January 2021

Accepted: 2 April 2021

Published: 8 April 2021

Publisher's Note: MDPI stays neutral with regard to jurisdictional claims in published maps and institutional affiliations.

Copyright: (C) 2021 by the authors. Licensee MDPI, Basel, Switzerland. This article is an open access article distributed under the terms and conditions of the Creative Commons Attribution (CC BY) license (https:// creativecommons.org/licenses/by/ $4.0 /$ )
Abstract: The main aim of the paper is to discuss the scale and nature of the practice of transmitting Holy Mass by parishes of the Roman Catholic Church in Poland through online live-streaming in spring 2020. The authors analyse these issues in a multifaceted and interdisciplinary way, mainly within the framework of communication and media studies and theology. The methodology of the paper combines practical theology (its four stages: "see-judge-act-review"), scientific methods applicable to social studies (especially social communication and media studies and sociological studies), and the technical aspect of communication activities (in the form of live video streaming) performed by parishes on the Internet. As it turns out, 40.8\% of Polish parishes carried out online Mass broadcasts. In most cases, the main sources of broadcast signal were YouTube (18.9\%) and Facebook (18.7\%), while less than $5 \%$ of the parishes conducted technically independent broadcasts. The research showed a statistically significant correlation between online Mass broadcasting and the region of Poland. There was a statistically significant difference between the parish size and Mass broadcasting - the larger the parish, the more often such activities were performed; a similar correlation was observed between urban and rural parishes. Research has shown that in the dioceses where bishops directly encouraged parish priests to broadcast from their parishes, the average percentage of broadcasts was higher (46\%) than in those in which there were no such incentives (38\%). There was a statistically significant relationship between having a website and conducting online Mass broadcasting. Similarly, there was a statistically significant relationship between the type of parish (conventual-diocesan) and online Mass broadcasting. Conventual parishes did this much more often than diocesan ones $(68.6 \%$ and $38.9 \%$ respectively).

Keywords: COVID-19; Poland; Holy Mass; broadcasting; Internet; new media; mediatization; religion; digital religion; mass media studies; pastoral theology

\section{The Mediatisation of Religion during the COVID-19 Pandemic: Introduction and Approach of the Analysis}

The COVID-19 pandemic is a subject of reflection from scholars from various fields of science and with different research approaches ${ }^{1}$. Many questions have arisen about its

1 In an earlier text, we examined the Polish media's discourse on the phenomenon of broadcasting the Eucharist during the COVID-19 pandemic in Poland (Jupowicz-Ginalska et al. 2021). Subsequent articles we are preparing will include, among others, an analysis of the Polish bishops approach to the broadcasting of the Eucharist and the perspective of the recipients of the broadcasts, who were deprived of the possibility of going to church for Easter and thus had to use media broadcasts. 
possible impact on the shape and functioning of societies: according to Sułkowski (2020), one of the most significant changes seems to be the virtualisation of communication as well as social and economic life, which-by affecting the sphere of religiousness-has accelerated and intensified the mediatisation processes of religion.

These issues will be analysed from a multifaceted and interdisciplinary theoretical approach. First, we will describe the context of this analysis, exploring the relevance of Internet in the mediatisation of religion. Then, to discuss the scale and nature of the practice of transmitting Mass by parishes of the Roman Catholic Church in Poland through online live-streaming ${ }^{2}$ during the COVID-19 pandemic, an approach based on theoretical and quantitative analyses will be used. The theoretical analyses will be based on three approaches: (1) theoretical aspects taken from social communication and media studies and sociological studies, (2) the "see-judge-act-review" paradigm that will be supported with quantitative techniques in order to undertake a deeper and systematic analysis of reality, and (3) the meaning and implications of the communication activities in the form of live video streaming. This approach partly corresponds to the method of interpretation "sub ratione Dei" proposed by $\mathrm{H}$. Seweryniak. It consists of two stages. In the first stage the researcher identifies the problem (cultural phenomenon, social phenomenon, cultural transformations, etc.). At this stage, the complexity of the phenomenon, the interdisciplinary nature of the issue, possible psychological or technical conditions, etc., must be taken into account. In the second stage, the researcher makes a theological interpretation of the problem (Seweryniak 2010, pp. 19-20).

\section{The Mediatisation of Religion and the Significance of the Internet}

To understand the context of the research described in this article, it appears necessary to refer to the theory of the mediatisation of religion. Mediatisation is defined as a "twosided process of a highly advanced modernity, where the media—on the one hand, emerge as an independent institution, with its own logic, to which other social institutions must adapt. On the other hand, the media simultaneously become an integral part of different institutions, such as: politics, work, family, and religion, because more and more actions are performed through the interactive mass media" (Hjarvard 2008a, p. 105). Religion, however, is only one branch of this complex and multi-faceted process of the media penetrating its logic into all areas of our lives. These processes have been quite carefully analysed and described in the literature on the subject (Adamski 2015; Asp 1990; Couldry 2008; Couldry and Hepp 2013; Deuze 2011; Goban-Klas 2020; Gomes 2016; Hjarvard 2008b; Krotz 2007, 2009; Lundby 2009, 2014; Tudor and Bratosin 2018), including a critical approach (Ampuja et al. 2014). Therefore, only those aspects that may be more relevant to understanding the context of the submitted studies will be discussed further below. According to Hoover (2011, p. 613), nowadays there is "a kind of dialectic relationship" between religion and the media, which makes a scientific reflection on religion and religiousness almost impossible without referring to the influence of the mass media. This is happening not only in the area of social sciences and humanities, but also in the field of theology. The theology of the mass media and communication is now recognised as an independent theological discipline, and due to its interdisciplinarity, the Polish scientific community considers it a fully-fledged research area within mass media and communication studies (Adamski and Łęcicki 2016; Butkiewicz and Łęcicki 2018; Chmielewski 2019, pp. 15-18; Jeżak-Śmigielska et al. 2018; Hofman 2018; Leśniczak 2018; Soukup 2019).

The relations between the media and religion have also been studied in the context of the broadly understood mediatisation of faith and religious practices (Campbell 2005, 2010; Campbell and DeLashmutt 2014; Berger 2013; Bratosin 2016, 2020; Giorgi 2019; Hjarvard 2011; Martino 2020; Mishol-Shauli and Golan 2019; Reimann 2017), including

2 We understand user-generated live video streaming systems to be services that allow anybody to broadcast a video stream in real-time over the Internet (Pires and Simon 2015, p. 225), which means distributing a video feed in real-time to some audience using either a recording camera or a mobile device (smartphone, tablet). Furthermore, it is viewed as common practice that video live-streaming also includes sound (Liljequist 2016, p. 6). 
media evangelisation (Chmielewski 2020), community building (Andok and Vígh 2018; Kołodziejska 2018; Sierocki 2018), and the celebritization of religious leaders (Mikuláš and Chalányová 2017). An important aspect is the phenomenon of televangelism (Bekkering 2018; Bretthauer 1995; Hoover 1991; Korpi and Kim 1986; Diekema 1991), as well as a reflection (in terms of technology, communication, and theology) on telepresence (Denson 2011; Sheppard and Walter 1999). A separate category of studies is the reflection on the virtualization of religion (Campbell 2013; Hutchings 2011; Lundby 2011; Skačan 2017; Young 2019), including its presence in so-called parallel worlds (Campbell 2004; Jacobs 2007).

In the light of the mediatisation theory, religion is becoming increasingly embedded in the logic of the media, both in terms of institutional regulations, symbolic content, and individual practices (Hjarvard 2008a, p. 11). This has many implications. The development of the media, including social media, has been one of the driving forces behind the breakthrough change in the communication of the Catholic Church and its leaders with the faithful and the public. The media have become not only a participant in church and religious life, but also an institution of pressure on its hierarchy (Pastwa 2020, p. 41). One could even say that the media themselves operate according to the logic of religion. To be more precise, they embody the power previously represented by the clergy, adopting the same status and the same prerogatives; although they are secular, they are no less dominant and exclusive (Tudor and Bratosin 2020; Wieczorek 2012). On the other hand, religious institutions are more and more willing to use social media and another marketing and public relations tools to protect and build their positive image (Graca 2020); also, violations of the principles of crisis communication with and through the media can be detrimental to the reputation of religious institutions (Gawroński and Majkowska 2018; Ignatowski et al. 2020; Leśniczak 2019, 2020; Tworzydło et al. 2020).

The mediatisation of almost all aspects of human life is based on increasingly better communication tools that transform time-space relations in communication (Drag 2020, p. 94). This is primarily related to the dynamic development of the Internet, understood not so much as a medium of communication, but rather as a metamedium-a new communication environment offering the possibility of creating media of virtually unlimited properties and communicating with others both in real-time and asynchronously (Adamski 2012, pp. 85-86). Communication is possible in any arrangement of its participants (one to one, one with one, one to many, one with many, many to many, many with many, one/many to all, one/many with all) (Pisarek 2008, p. 145). Thus, any participant in online communication can be both a sender and a recipient.

This feature of online communication makes it, on the one hand, a very good tool for all activities related to religiousness, and, on the other, it stimulates, strengthens, and accelerates the process of the mediatisation of religion. In evangelisation, it can (similarly to the "traditional" media) perform pre-evangelisation (preparatory) and pro-evangelisation (supporting) functions (Cymanow-Sosin 2020, p. 184). The Internet circulates religious ideas in many ways and methods, for instance: holy texts in multimedia form and websites of churches, online religious channels, blogs, and online religious service, using elements of religious content or history in computer games, etc. (Szocik and Wisła-Płonka 2018, p. 86). Nevertheless, a distinction should be made between religion online and online religion ( Helland 2000). "Religions online" are characterised by low interactivity, institutionalisation of the sender, the "one-to-many" communication model, information transfer, and participation opportunity. It is therefore closer to the hierarchical religions existing in the analogue world. Conversely, "online religions" manifest such features as: high interactivity, the non-institutionalised broadcaster, community building, and a "many-to-many" communication model. These communities often exist only on the Internet and do not meet in one place or time, without media involvement (Hanas 2013, p. 30).

For the Roman Catholic Church in Poland, the Internet is an important tool for communication. All Roman Catholic dioceses in Poland have their own websites, with the development of these closely linked to the involvement of a church team of specialists (Robak 2018, p. 386). 
The percentage of theological seminaries (run by dioceses and religious orders) in Poland where media education is taught is also constantly growing (from 6 universities out of 84 existing in 1992 to 47 in 2017) (Kasowski 2018). The new ratio studiorum for seminaries in Poland makes this subject obligatory (Idziemy.pl/rm 2020). According to the guidelines of the Congregation for the Clergy, the range of topics to be covered should include media theology, knowledge of the role of digital media for evangelisation, a profound understanding of the media world (in terms of both audiences and creators), developing media competence, and social media. In total, out of eight issues related to human formation, as many as three concern the media, including the Internet (Chmielewski 2019, p. 20).

The percentage of parishes using websites and social media is varied. Unfortunately, there are no reliable studies to determine the number of parishes that provided online broadcasts before the pandemic. According to Makuła (2019, pp. 40-41), the Church in Europe used live broadcasts much less frequently than in the USA, Africa, or South America. It should be remembered, though, that the phenomenon of broadcasting religious events over the Internet is relatively new. To a large extent, this is due to technical conditions such as Internet bandwidth and increasingly improved algorithms for image and sound compression, which make it possible to stream audio-visual content. It is sufficient to note that the Skype online communicator, which revolutionised online communication technology, was only created in 2003 (Adamski 2012, p. 39), and the limitless possibility of live-streaming on Facebook for all users was only introduced in 2016. Thus, social media became an important tool of online live-streaming (Makuła 2019, p. 40). It should be stressed that this feature is not only used for broadcasting Masses or church services, but is also used in group communication, youth meetings, etc. (Gralczyk 2020, p. 241). The aims of online religious live-streaming include evangelising youth (e.g., pushing the boundaries of religious socialisation to fit the media-saturated environments of the contemporary youth) and maintaining a constant presence of the transcendental (e.g., generating a readily accessible experience of engaging with sites that utilise new media tools to mediate the divine) (Golan and Martini 2019).

\section{The Analysis of the Problem from the Point of View of the Parishes of the Roman Catholic Church in Poland: Insights from Elements of Communication and Media Issues}

The interdisciplinary (or even transdisciplinary) nature of the paper requires a theoretical foundation in communication and media issues, as well as an explanation regarding the nature of the structure of the Roman Catholic Church in Poland, including reflections on the hitherto use of the Internet for communication with the faithful at the parish level. According to the provisions of the 1993 (ratified in 1998) Concordat between the Republic of Poland and the Holy See, the organisational structure of the Roman Catholic Church in Poland should be limited within the territorial borders of the country. This means that no part of the Polish territory can be included in a diocese or church province with its capital outside the borders of Poland, and no diocese with its capital in the Republic of Poland can spread beyond the borders of Poland (Concordat 1998). This does not mean, however, that it is necessary to duplicate the system of regional division in Poland-there are differences concerning the structures of the state and the structures of the Church.

According to the territorial division approved by Statistics Poland (GUS), Poland is divided into "voivodships". Voivodships are divided into "powiats" and cities with powiat rights, and powiats are divided into "gminas". Gminas consist of settlements (cities, towns, and villages). "As of 1 January 2020, the administrative division of Poland included: 16 voivodships, 314 powiats, and 66 cities with powiat status, 2477 gminas (including 302 urban gminas, 642 urban-rural gminas, and 1533 rural gminas)" (Statistics Poland 2020a). Towns and cities ("miasta") in Poland are settlements with city rights or city status granted according to the procedure set out in the relevant regulations ${ }^{3}$ (Statistics Poland 2020b).

3 In Poland there is no difference between a city and a town. 
The Roman Catholic Church in Poland is divided into dioceses, with those divided into vicariates forane (decanates/deaneries), and those into parishes, which are the basic territorial unit. The (1983, can. 518) distinguishes between territorial parishes, which lie within a certain territory, and personal parishes, which include a group of believers defined according to rite, language, nationality, or on some other basis. A parish consists of one settlement (or part of it) or several settlements. In terms of size, a parish is a unit of division larger than a settlement, but smaller than a gmina. When determining the population of a parish, it is usually assumed that it is equal to the number of people who live within its territory, regardless of their religion (Sadłon 2013, p. 38). However, another approach is to consider the number of parishioners to be the number of believers-that is, people who have declared their affiliation to this particular community. This is particularly important in places inhabited by people of different faiths or in areas which are highly secularised.

Although the territorial boundaries of parishes do not overlap with those of gminas, there are three types of parishes / gminas in both state and church structures (as a formal division based solely on the administrative criterion):

- urban gminas/parishes: their boundaries coincide with the boundaries of the city or town forming the gmina (18.9\% of the total);

- urban-rural gminas/parishes: they include both the city or town within its administrative boundaries and areas outside these boundaries (15.6\% of the total);

- rural gminas/parishes: they do not have a city or town within their area $(65.5 \%$ of the total) (Sadłoń 2013, p. 38; Zdaniewicz 2001).

Another criterion of division includes diocesan parishes (run by diocesan priests) and conventual parishes (run by clergy belonging to a particular religious order). According to the "Annuarium Statisticum Ecclesiae in Polonia AD 2020" report, the total number of parishes in Poland is 10,356, of which 9695 are diocesan parishes and 611 are conventual (Institute for Catholic Church Statistics 2020).

Each parish is a defined structure: it includes a group of people living in a given territory. Inside a parish, there is a certain communication structure, which can be described as a network. The central node of the parish network is the parish priest (in Poland, there are practically no parishes in which the parish priest does not live), other important people are the parish leaders, who are usually close associates of the parish priest (Sadłon 2013, p. 39). This networking is supported by various means of communication. The basic ones are liturgical gatherings, especially on Sundays, along with announcements made on that occasion. Parishes support each other in ad intra and ad extra social communication activities. According to data for 2016, an average of 32.4\% of Polish parishes published content in paper form (this percentage, however, varied greatly from $9.3 \%$ of parishes in the diocese of Drohiczyn to $75.7 \%$ in the diocese of Opole). On average, $24.5 \%$ of Polish parishes published parish press: $3 \%$ books, $8.2 \%$ brochures, and $8.8 \%$ other paper publications (the Institute for Catholic Church Statistics 2018, pp. 43-45). However, nowadays "the territorial configuration of the Parish (...) must confront a peculiar characteristic of our contemporary world, whereby increased mobility and the digital culture have expanded the confines of existence" (Congregation for the Clergy 2020, p. 8). For this reason, parishes are increasingly interested in electronic publications and communication via websites and social media. In 2019 , as many as $72.7 \%$ of Polish parishes published content in electronic form, with $62.6 \%$ of the parishes having a functioning website and $6.4 \%$ declaring that a website was being developed. The highest rate was recorded in the Archdiocese of Katowice (89.2\%) and Warsaw $(88.8 \%)$. The smallest percentage of parishes with a website was in the dioceses of Łomża (38.2\%) and Kielce (42.6\%). (Institute for Catholic Church Statistics 2020, pp. 38-39).

\section{The Practice of Transmitting the Holy Mass by Internet in Poland: The Four Stage Analysis}

As mentioned, the paper is based on interdisciplinary methodology, which combines practical theology (in its four stages: "see-judge-act-review"), scientific methods applicable to social studies (especially social communication and media studies and sociological 
studies), and the technical aspect of communication activities (in the form of live video streaming) performed by parishes on the Internet. For this reason, the authors of the paper departed from the frequently used IMRaD (introduction-methodology-research and discussion) structure in favour of a structure based on the "see-judge-act-review" methodology. Within this structure, we draw on other research methods, mainly from the social sciences.

The next points are based on the subsequent stages of the "see-judge-act-review" paradigm, which is an extension of the "see-judge-act" version, popularised by Cardijn (Britannica 2013) and adopted as a valuable method used in pastoral theology, especially in the context of recognising the signs of the times. It has become an important strategy of developing documents of the Catholic Church and local churches as well as a method that is still used today in pastoral theology (Young Christian Workers 2020). This approach is not equivalent to the traditional methodology used in social sciences research and journals, but it is justified to use this paradigm as a way of interpreting the world. In fact, it appeared as an educative resource directed to facilitate the application of abstracts learning to specific situations in order to transform the social reality.

It is worth pointing out that the first document to refer to the "Cardijn paradigm" was the Mater et magistra (John XXIII 1961) encyclical by John XXIII, followed by the Pastoral Constitution on the Church in the Modern World Gaudium et spes (Pope Paul VI 1965). This paradigm has been constantly deepened in pastoral theology. In Latin America, brothers Leonardo and Clodovis Boff, involved in liberation theology, focused on the sociological aspects and necessary social transformations, which triggered a wave of criticism of the method being too "revolutionary" (Sands 2018) and thus it was not used for a certain period. Even though the method was still criticised at the beginning of the Fourth Episcopal Conference of Latin America in Santo Domingo, at its end it began to be extended to include further stages, such as "review" and "celebrate" (Midali 2011). This critical phase has been overcome, and during The Fifth Episcopal Conference of Latin America and the Caribbean, or "Conference of Aparecida", it was used again. It was also used by other episcopate conferences, e.g., in Africa, Asia, and North America. It was later adopted by John Paul II in his Sollicitudo Rei Socialis encyclical (John Paul II 1997), as well as by numerous pastoralists (e.g., Kiciński 2011; Mette 2005).

Therefore, in the adaptation of the principles of the aforementioned method to the formal structure of this paper, it should be pointed out that at the "see" stage, it is necessary to gather thorough knowledge regarding the situation in which the Catholic Church (in this case, the Church in Poland) found itself when the pandemic broke out. The authors pose the following research questions in this regard: What was the reaction of the state authorities to the outbreak of the pandemic? How did the restrictions and limitations affect the increase in the role of the Internet in the activities of many institutions, including religious institutions? Were they prepared for this situation in terms of technology and competence?

At the "judge" stage, reference should be made to everything that helps to assess the previously analysed situation, e.g., the resources of knowledge and solutions available, including the Church's teaching on Mass broadcasts in the media. Here, the research questions are: What was the historical development of Church legislation on the broadcasting of Masses and services? How are they supposed to proceed? What are the theological and canon law assumptions of Internet broadcasting? Who should use them? What are their limitations?

At the "act" methodology stage, reference should be made to specific pastoral actions undertaken following the teachings of the Church. The authors investigate issues surrounding: Who was to follow the instructions of the bishops and how? How did parishes communicate with the faithful? How many parishes were able to broadcast Mass? What problems could there be in different areas of Poland?

At the "review" methodology stage, a discussion should take place on the adopted goals and an attempt should be made to answer questions about the implementation of online Mass broadcasts in Poland during the first phase of the COVID-19 pandemic. What 
strengths and weaknesses of online pastoral activity emerged in Poland? What are the possible reasons behind the scale of efforts made by parishes to broadcast Sunday Mass on the Internet? Has the outbreak of the pandemic contributed to the intensification of the mediatisation processes of religion in Poland concerning the Roman Catholic denomination?

\section{1. "See"-The Outbreak of the COVID-19 Pandemic and the First Reactions from State Authorities, the Holy See, and Bishops}

The first COVID-19 case in Poland was confirmed on 4 March 2020. Although the following days did not bring about a sharp increase in cases, the Polish authorities reacted promptly and with determination. Sanitary checks were introduced at national borders on 9 March, mass events were cancelled on 10 March, and the following day school classes were suspended (educational units switched to distanced learning). A state of epidemic emergency was declared on 12 March, with 49 cases across Poland. Along with this, further restrictions were announced: limitations on the functioning of shopping centres and the prohibition of public (including religious) gatherings of over 50 people (both in the open air and in buildings). Institutions of culture, sport, and entertainment were also closed. Since 20 March, a state of epidemics began, which involved, among other things, an increase in the punishments for violating quarantine rules and further tightening of restrictions on the freedom of movement and assembly. The last restriction also applied to participation in Masses/religious ceremonies. No more than five people were allowed to attend at the same time (other than those performing the service). It is important to note that the authorities at the time explicitly encouraged practising religion through the media-via the radio, television, or the Internet (Serwis RP 2020). At the beginning of April, further restrictions were announced: the number of customers in shops was reduced; hotels, beauty salons, forests, parks, and beaches were closed; a strict sanitary regime was introduced; and regulations for e-learning or the number of people in, e.g., churches were extended. This meant that the limits of the faithful were in force during the Paschal Triduum. Additionally, an obligation to cover the mouth and nose in public places, e.g., on the street, in shops, and in churches, was announced (this rule did not apply to soldiers, small children, or clergy performing religious rituals).

On 20 April, the restrictions began to be gradually eased. During the first stage of easing (20 April-3 May), forests and parks were opened, and more people were permitted into churches providing each person had $15 \mathrm{~m}^{2}$ space. The second stage (4-17 May) marked the opening of shopping centres, hotels, sports facilities, selected cultural institutions, and early school education institutions. During the third stage (18-19 May), the limit of believers at religious ceremonies was increased (with $10 \mathrm{~m}^{2}$ allocated per person); open-air cinemas, beauty salons, and restaurants were opened; and film sets or recording studios started working again. The restrictions on education and sports facilities continued to be lifted. In the fourth stage (from 30 May), gyms, hotels, and other cultural institutions were opened. Meetings of up to 150 people were allowed (with the mandatory wearing of masks or keeping social distance). The organisation of congresses and fairs was permitted. The limit on the number of believers in places of religious worship was cancelled; the requirement to cover one's nose and mouth was maintained; however, it did not apply to people staying outside the church and keeping a distance of one and a half metres. It should be noted that the following months, starting in August 2020, brought an increase in the number of cases, and since October a second wave of the pandemic has been observed. However, even though the curve of infections in the autumn period increased more rapidly (with up to 28,000 cases per day), the authorities did not decide to re-announce a lockdown or to implement such severe restrictions on the number of believers in places of religious worship. For this reason, the second wave of the pandemic (the arrival of which was predicted) is not the subject of research in this paper.

It is worth pointing out that the first wave of the epidemic forced those in society to change their lifestyles in practically every sphere, from work and study to entertainment and the practice of religion. During the lockdown, Poles resorted to the Internet to carry out their duties and maintain at least the illusion of normality. The pandemic 
has triggered a significant increase in the role of this medium in private and professional communications around the world. A survey conducted in April 2020 in the USA showed a significant increase in the use of electronic communication, mainly text messages (43\%), voice calls (36\%), and social media (35\%) (Nguyen et al. 2020, pp. 2-3). In Poland, $42 \%$ of employees performed their work online (Drozdowski et al. 2020, p. 33). This required not only the use of professional real-time communication tools but also the improvement of internal organisation (e.g., document circulation). Companies accelerated their digital transformation by introducing advanced digital solutions and often transferred all of their activities to the Internet (Debkowska et al. 2020, pp. 33-34). As a result, the demand for increased Internet capacity rose, whether for teleworking, e-learning, or entertainment. The increase in network traffic is particularly visible in online conferences (300\% in the USA) and online games (400\% in the USA, $100 \%$ in Poland). As far as video streaming is concerned, traffic increased especially in the morning and early afternoon, in some cases by almost $100 \%$. This even led to the intervention of the EU Commissioner for the Internal Market, who appealed to streaming service platforms to lower their bit rate (European Commission 2020; Ambroziak et al. 2020, pp. 7-9). The burden on the ICT network did not directly affect parishes wishing to broadcast Sunday Mass, because on Sundays the system was not as heavily loaded as on weekdays.

The response of the Roman Catholic Church institutions in Poland to the outbreak of the pandemic was fairly moderate and in line with the reactions of Pope Francis and other religious leaders (not just Christian ones). The pandemic was considered a potential threat to the health and lives of participants in the liturgy, so the restrictions on the number of participants in the liturgy, introduced by the state authorities, were generally accepted with understanding, even though they occurred during Easter, which is the most important Christian holiday. "The closure of churches and the prohibition of the celebration of the sacraments in the presence of a congregation created a stark divide between the individual and their Christian community" (Parish 2020). For all religious communities, this was a new situation, and one which posed the question of how to ensure the possibility of member participation in the liturgy and the experiencing of this in real-time, in unity with other participants. It was all the more difficult given that during the period of extreme restrictions the number of liturgical participants was limited to five (not including the celebrant), while the period of the Paschal Triduum and Easter is traditionally associated in Poland with crowded churches. Therefore, it was necessary to review and interpret the existing situation according to the sub ratione Dei principle (Seweryniak 2010, pp. 19-20), that is, from the point of view of faith and the word of God.

Pope Francis complied with the Italian sanitary rules and recommended adhering to them. It was the decision of the Pope that from 9 March 2020 daily Mass was to be live-streamed from the Domus Sanctae Marthae under his leadership. His first intention was to pray for those suffering from coronavirus, for doctors and nurses, for volunteers who help them, for all the members of their families, as well as for the elderly staying in old people's homes and for those in prison. On the following days, until the live-streamed broadcast ended on 18 May 2020, he extended his prayer intentions to include prudence during the pandemic and for its termination; he also prayed for those who had died of coronavirus and for wisdom for governments in managing the pandemic as well as for the unity of Europe. Francis, while emphasising the value of broadcast during the pandemic as a sign of closeness with the faithful and as a possibility of receiving Christ in spiritual communion, warned against the virtualisation of faith (Francis 2020). At the end of the lockdown, he expressed the desire for the faithful to return to normal sacramental life through personal participation in the liturgy.

Almost all churches and communities were ready to make some changes to their practice of worship, from modification through the restrictions to suspension. The decisions taken in this regard depended on ecclesiology and how the Church was governed. In Poland, individual churches either limited (the Catholic and the Orthodox Churches) or completely suspended (the Protestant Church) their religious lives in a real community 
dimension, yet they all maintained contact with their faithful in various ways, using modern technology and access to public media (Sulkowski and Ignatowski 2020).

\section{2. "Judge"-Theological and Legal Reflection to Date on the Broadcasting of the Eucharist}

The very fact of broadcasting the Eucharist is not a new phenomenon. Questions regarding the possibility of broadcasting Masses and services appeared just after the invention and dissemination of the radio, at the beginning of the 20th century. However, the initial position of the Holy See on this issue was sceptical, and the bishops who decided to formulate official questions on this issue received discouraging responses (Radej 2020, pp. 97-98). Essentially, the theological doubts which existed at the time can be reduced to three main points:

- it was feared that the faithful would treat radio broadcast as sufficient to comply with the duty to attend the Eucharist on Sundays and holy days of obligation, replacing direct participation at the place of celebration with the concept of indirect participation, treated as an intentional act;

- the problem was raised of possible inadequacy of the place where the broadcast was received, but doubts were also voiced concerning the radio as a medium: it was pointed out that it was not suitable to listen to the words of the Eucharist from a device which sooner or later would provide inappropriate music or words perceived by Catholics as offensive to God and religion or even blasphemous;

- the danger of losing the liturgical essence of the Eucharist was pointed out, as it is impossible to physically receive Holy Communion (Szczepaniak 2012, p. 16).

In view of grassroots pressure from various bishop's capitals and after consultation with theologians, in 1936 the Holy See allowed the Eucharist to be broadcast over the radio, with the provision that, for those who are able to go to church for Sunday Mass, listening to the radio broadcast is not the fulfilment of the obligation to participate in the Sunday Eucharist (Draguła 2009, p. 33). Interestingly, with regard to the broadcasting of Mass on television, such controversies hardly occurred. Still, the subject of broadcasting the Eucharist required in-depth theological reflection. Two documents are the result of this reflection: John Paul II's (1998) apostolic letter Dies Domini, and the post-synodal apostolic exhortation of Benedict XVI (2007) Sacramentum caritatis. The main points of this stance are as follows:

- the very fact of broadcasting the Eucharist is a positive phenomenon, with broadcasts being of "valuable help" (John Paul II 1998, p. 54) for those who, for serious reasons, cannot physically attend the Eucharist. Draguła (2020a) refers this point to the theology of the image, formulated by the Second Council of Nicaea against iconoclasts: "He who pays homage to the image, pays homage to the Being it represents" (BF 1988, p. 637). Therefore, praying and performing gestures in front of a radio receiver or screen refers to the reality of the mystery which is performed at the same time but in a different place;

- although "disease, disability, or other serious cause" (John Paul II 1998, p. 54) exempt you from the obligation to participate in the Eucharist, they does not blur the nature of the holy day. In such situations it is necessary to attend Mass "from afar" (John Paul II 1998, p. 54). As an essential means of this participation, the document mentions the Mass readings and prayers as well as the desire for the Eucharist (John Paul II 1998, p. 54). Broadcasts give the opportunity to "unite with the Eucharist celebrated in holy places" (John Paul II 1998, p. 54), but are not necessary for this. What is more important is individual and community prayer, Mass readings and, above all, spiritual communication with the community of believers. "The Church intends to give priority to living prayer, whether individual or in community, whereby the broadcast is only supposed to help. It is not an aim in itself, but a spiritual union with the praying Church. Broadcast is only a means, a relatively necessary means" (Draguła 2020a). Therefore, it is considered unacceptable to participate in a broadcast recording released in the form of a podcast, as this solution does not meet the requirement for 
participation "here and now". This is evidenced by the reaction of bishops to the fact that recordings of Mass broadcasts were posted by some parishes on their social media profiles. For example, the Bishop of Opole decreed: "Records of religious rituals must not be published after they have finished. They may only be broadcast in real time (live-streaming). All past recordings, which can be found on parish websites and in their social media, which contain religious rites, are to be removed within seven days of the promulgation of this Decree. However, photographs are allowed to remain" (Czaja and Lippa 2020);

- $\quad$ participation in the broadcast Eucharist by a person who has no obstacle in going to the church is not in the fulfilment of the Sunday duty (John Paul II 1998, p. 54; 1997, p. 57). Therefore "despite allowing the Holy Mass broadcast, listening to it (even actively, with giving responses, singing, assuming the adequate posture at the specific moment in liturgy) is not an ordinary way of participating in the liturgy" (Adamski 2019, p. 242).

A slightly broader dimension is shown by the Directory for the Mass broadcast by television, adopted by the Polish Episcopate in 2017. This document emphasises that the broadcasting of the Eucharist through television and the radio has primarily a pastoral justification, and this applies mainly to the pastoral care of the sick and the elderly. It stresses that through broadcasts they can "establish a spiritual connection with the faithful who participate in the Eucharist in a particular church in order to listen to the word of God and to unite their sufferings with the sacrifice of Christ" (Konferencja Episkopatu Polski 2017, n. 8, p. 49). It also points to the evangelistic and formative dimension of broadcast. The evangelistic dimension means that the broadcast is a testimony to the faith of the community of believers and an opportunity for the proclamation of the Gospel, while the formative dimension imposes an obligation on the broadcasters to ensure that the Mass broadcast can serve as a model for the preparation of the liturgy; moreover, churches which are outstanding in their beauty and design should be selected for the broadcast (Konferencja Episkopatu Polski 2017, n. 9-11, p. 49).

It should be noted that the Directory does not refer to Mass broadcasting by parishes using the Internet and live-streaming technology. Online broadcast is technically different from that of television or radio; it is certainly easier to implement as it does not require any specialist equipment-a smartphone, tablet, or computer with a camera and microphone plus a relatively fast Internet connection are sufficient. Nevertheless, during online broadcast, the possibility of the so-called streaming latency should be anticipated (including latency of seconds when the connection is slow) (Ruether 2019). Secondly, it must be taken into account that in the case of live broadcasts using social media (Facebook, YouTube), the recipient may be distracted by notifications or comments appearing in pop-up windows. The option of live commenting may also be an obstacle in focusing on Mass (Makuła 2019, p. 41). On the other hand, there is more authenticity in online broadcasting than in television broadcasting. Among the important elements of a broadcast are camera movement and angle, zooming in and out on objects, and above all, the use of various filming locations. At the editing stage, a sequence of frames, shots, and scenes creates a certain composition, i.e., a narrative sequence. It is often dynamic editing that determines the effectiveness of the message (Szczepaniak 2018, p. 83). In contrast, online broadcasts are rarely made using professional editing techniques. As a rule, the image is still-transmitted from a camera or a mobile device fixed on a tripod so that the frame covers the presbytery. It is closer to the experience of participating in a live liturgy, where the participants are usually in the same place all the time, without changing their perspective, distance from the celebrant, or the angle at which they watch the liturgical action.

It should also be noted that there are no regulations concerning the behaviour of the faithful who participate in the broadcast service. During the pandemic, there were numerous guides in this area. For example, the KEP (the Polish Bishops' Conference) spokesman commented on this, suggesting that the Mass should be experienced in the same way as it is in church-by performing relevant gestures, by engaging in singing and 
recitation, or by responding to the words of the celebrant. Those who are in the state of grace should receive spiritual Holy Communion. There were also various practical tips: the faithful ought to choose the same time for all members of the household in advance and participate in the broadcast Mass with the whole family, gather a few minutes before the start of the broadcast, highlight the importance of the event by festive clothes and decorations (e.g., lighting candles), adopt an appropriate position of spirit and body, and refrain from commenting (Biuro Prasowe KEP 2020b; Archidiecezja Krakowska 2020; Wielgosz 2020; Stacja7 / redakcja 2020).

\section{3. "Act": Online Communication Tools for Spiritual Communication between the Parish and the Faithful-Empirical Studies}

This section explains what actions (act) have been taken by the Roman Catholic parishes in Poland after confronting the epidemic situation (see), reflecting on the resources at their disposal and on the previous experience of the Church (judge).

\subsubsection{Church Action in Response to the Pandemic Situation}

Among the actions taken by the Catholic Church in Poland, the main one was the dispensation from participating in Sunday Mass granted by diocesan bishops. One must agree with Draguła (2020b) that from a legal standpoint this was not necessary, as the reality of the pandemic was an objective reason which made it impossible to fulfil the obligation to participate in the Sunday Eucharist. Under these circumstances, the purpose of the dispensations was merely to appease the consciences of the faithful. Nevertheless, the Church authorities realised that mere dispensation was a temporary remedy rather than a permanent solution for the situation. Prolonged restrictions could be detrimental to the religious sensitivity of the faithful and damage their bonds with their home parishes. Therefore, in many cases, dispensation decrees resembled practical pastoral guides, indicating possible ways of alleviating the negative effects of this situation (e.g., on a spiritual, emotional, and psychological level). These indications can be classified within three main trends:

1. Non-media pastoral non-standard (ambient) activities. For example, parish priests helped the faithful to participate in Mass outside the church building (keeping social distance) by putting loudspeakers outside (Cylka 2020); the faithful could attend Mass in cars parked on the church car park (where a sound system had been installed); mobile confessionals were set up, Easter food was blessed from a car or motorbike moving through the village, as well as many other activities which are unusual from the pastoral point of view (Dobrołowicz 2020; Xiong et al. 2020, p. 26).

2. Large-scale Mass broadcasts by the media (via the radio, television, and the Internet). Several radio and television stations (including liberal and secular ones, and not only those considered strictly religious or pro-Catholic) changed their schedules to include Sunday Eucharist broadcasts. Market research has shown that this step generated a significant increase in their audience (even a ten-fold increase in the case of the niche TV channel Polsat Rodzina, Kurdupski 2020). Interestingly, such actions were also carried out by cable operators, who decided to broadcast Masses from local parishes. Thanks to this, the maintenance of bonds and community in difficult times was ensured not only in a general dimension, but also at a sub-local level, focused on the individual and local churches (NB 2020).

3. Grassroots initiatives of parishes to independently broadcast the Mass over the Internet. The stimulus for such activity was, among other things, provided by incentives from diocesan bishops. Therefore, naturally, questions about the scale of this phenomenon and reasons for parishes to undertake (or not to undertake) the discussed activities appeared. It is also noteworthy that the rapid and rather uncontrolled increase in the number of online broadcasts from parish churches departed from the practice sanctioned by Church documents to date. Before the outbreak of the pandemic, the benefit of broadcasting Masses was appreciated by the Catholic Church, 
which held a favourable attitude towards the broadcasts. Still, it was rather cautious from the points of view of theology and canon law. It is worth mentioning that it is this trend that is the subject of the empirical research presented here.

This third stage of the process is addressed using quantitative indicators concerning broadcast. The following issues have been analysed in detail: (1) what percentage of Polish parishes broadcast Sunday Masses?; (2) what was the basic source of the transmission signal?; (3) did parishes use social media for broadcasting? If so, which ones?; (4) was the signal from the primary source divided into other channels (e.g., from YouTube to Facebook, from Facebook to the website, etc.)?; and (5) is there a statistically observable link between the frequency of broadcast and the geographical location of parishes (a region of Poland), the size and type of the parish (diocesan/conventual or urban, rural, urban-rural) and the following variables: the dominicantes/communicantes indicators and the ratio of the number of priests to the number of Catholics in a given diocese?

\subsubsection{Sample of Reference and Procedure}

The analysis developed in this part of the present article was carried out between 28 March and 31 May 2020, using a coding key inserted in an Excel sheet, covering 1533 Roman Catholic parishes from 41 dioceses that administer the liturgy in the Roman rite. The coding itself was carried out by coders and the results obtained were cross-checked at the end of May 2020. The Military Ordinariate parishes (which in Poland function as dioceses) were not included, nor were the two dioceses of the Byzantine-Ukrainian rite, the Byzantine-Slavonic rite (after the coding phase, on 25 November 2020, the third diocese of the Byzantine-Ukrainian rite was established), as well as the Ordinariate for Eastern Catholics in Poland (Latin: Ordinariatus Poloniae). The Military Ordinariate covers the whole territory of Poland. Some parishes are typically military, but there are also civilmilitary parishes. Decanates are created on the basis of different types of armed forces and military districts rather than on the basis of territorial division. Moreover, chaplains of the Polish Army also work abroad, where Polish soldiers take part in international missions. The dioceses and ordinariates of other liturgical rites also cover the whole territory of Poland. The faithful of these rites recognise the Pope as the head of the Church, but have their own parishes, decanates, and structures. Therefore, according to the authors, the organisational character of these church units and their functioning in the same territory as Roman Catholic dioceses could distort the results-hence the decision was taken to exclude them.

The minimum research sample for the specified number of Roman Catholic parishes in Poland $(10,356)$ with a $95 \%$ confidence level and 3\% statistical error allowed is 967 . This number was calculated according to the following formula:

$$
N_{\min }=N P(\alpha 2 \cdot f(1-f)) / N P \cdot e 2+\alpha 2 \cdot f(1-f)
$$

where:

- $\quad N_{\min }$-minimum sample size;

- $N_{P}$ - size of the population from which the sample was taken;

- $\quad \alpha$-confidence level for the results, the value of result $\mathrm{Z}$ in the normal distribution for the assumed level of materiality, e.g., 1.96;

- $f$-fractional size;

- $\quad e$-assumed maximum error, expressed in a fractional number, e.g., $3 \%$ is 0.03 .

The authors decided on a quota selection of the research sample so that the quantitative relations between different sizes and types of parishes are preserved in the sample structure. As far as the type of parish is concerned, two distribution criteria were applied:

- Conventual and diocesan parishes;

- Rural, urban-rural, and urban parishes. 
As far as the size of the parish is concerned, the following division was adopted:

- From 0 to 1000 believers-the group of parishes with the smallest population, consisting mostly of rural parishes and sometimes small urban parishes. The staff is usually limited to one parish priest. The percentage share in the sample is $15.3 \%{ }^{4}$;

- 1001-3000 - the largest group of parishes. Depending on the diocese, the number of 2500-3000 believers is the threshold for assigning more priests to the parish to help the parish priest. The percentage of the sample is $47.8 \%$;

- 3001-6000 - a group of relatively large parishes, including rural, urban-rural, and typically urban parishes. There are usually $1-2$ vicars assigned to help parish priests in such parishes. The percentage of the sample is $18.3 \%$;

- 6001-10,000-a group of large parishes, usually urban or urban-rural, where the parish priest is assisted by $3-4$ vicars. The percentage of the sample is $8.7 \%$;

- Above 10,000-the largest parishes, usually in medium and large cities, with numerous pastoral staff. The percentage of the sample is $9.9 \%$.

The authors, motivated by the wish to increase the accuracy of the survey, decided to widen the sample because not all dioceses publish the number of the faithful in each parish on their websites. In fact, during the survey, it seemed that this information was confidential in some dioceses. Therefore, a small number of parishes lack data on their population.

The subject of the research was the broadcasting or not broadcasting of at least Sunday Mass online by parishes of the Roman Catholic Church in Poland. It was assumed that a parish broadcasting the Eucharist was a parish which at least once provided a live broadcast of Sunday Mass celebrated in the parish church or in one of the filial churches within the parish area (in some dioceses, individual parishes encompass several churches). The broadcast could include sound and video or just sound (the radio). In order to be recognised, the broadcast had to be live-streamed, with the involvement of priests or local parishioners. The methods and technical aspects of the broadcast were not taken into account.

The data on broadcasting (or not broadcasting) was obtained in several ways. The first source was the analysis of information about parishes on diocesan websites, followed by the search of the website of a particular parish (through the diocesan website or a search engine) and the analysis of the website, including possible data concerning broadcast or links to social media profiles. If, however, the broadcast could not be confirmed, current and archival parish announcements were analysed and attempts were made to find the parish profile on Facebook and/or YouTube. The data obtained were coded on a spreadsheet according to the following criteria:

- which diocese a parish belongs to (the number of parishes from a given diocese was determined according to the total number of parishes in that diocese in proportion to the population);

- type of parish: diocesan or conventual;

- type of parish: rural, urban-rural, or urban;

- $\quad$ size of the parish;

- territorial assignment to one of the nine areas of Poland (north-east, north-centre, north-west, east-centre, centre, west-centre, south-east, south-centre, south-west ${ }^{5}$ );

\footnotetext{
4 The percentages of each parish group in the sample were established on the basis of: Zdaniewicz, n.d.

5 The classification of individual dioceses according to their territories:

1. north-east: the dioceses of Ełk, Warmia, Łomża, Białystok, Drohiczyn

2. north-centre: the dioceses of Elblag, Gdańsk, Pelplin, Bydgoszcz, Torun

3. north-west: the dioceses of Koszalin-Kołobrzeg, Szczecin-Kamień Pomorski

4. east-centre: the dioceses of Lublin, Warsaw-Praga, Siedlce

5. centre: the dioceses of Płock, Włocławek, Łódź, Łowicz, Warsaw, Radom

6. west-centre: the dioceses of Zielona Góra-Gorzów, Poznań, Gniezno, Kalisz

7. south-east: the dioceses of Sandomierz, Zamość-Lubaczów, Przemyśl, Rzeszów, Tarnów

8. south-centre: the dioceses of Kielce, Cracow, Częstochowa, Gliwice, Sosnowiec, Katowice, Bielsko-Żywiec

9. south-west: the dioceses of Wrocław, Legnica, Świdnica, Opole
} 
- classification of dioceses according to two indicators: dominicantes (percentage of believers attending Sunday Mass in relation to all believers) and communicantes (percentage of Catholics receiving Holy Communion during Sunday Eucharist in relation to the total number of believers) (data from the Institute of Statistics of the Catholic Church of 21 October 2018 (Institute for Catholic Church Statistics 2020) as well as data on the number of priests per 100,000 Catholics (data for 2017 [Institute for Catholic Church Statistics 2018]));

- the role of diocesan bishops in encouraging priests to broadcast Sunday Mass (data from analyses of documents-bishops' decrees, pastoral letters, and others-published on diocesan websites);

- at least one Sunday Mass broadcast by the parish;

- broadcast channel (Facebook, YouTube, other technical solutions, e.g., websites, service providers etc.);

- broadcasting on their profiles or using profiles of other persons/institutions (if social media were used);

- $\quad$ sharing the broadcast signal with other channels (e.g., a website).

The data were encoded by a team of four coders, following cross-coding rules (crosscoding, multiple coding), based on the coding of the same data by different people in order to improve its reliability.

\subsubsection{Polish Parishes and Mass Broadcasts-Research Results}

As it turns out, $40.8 \%$ of Polish parishes carried out online Mass broadcasts (Table 1 ).

Table 1. Percentage of parishes broadcasting Mass online.

\begin{tabular}{cccc}
\hline & & Number & Share \\
\hline \multirow{2}{*}{ Did the parish } & Yes & 626 & $40.8 \%$ \\
broadcast online? & No & 907 & $59.2 \%$ \\
& Total & 1533 & $100.0 \%$ \\
\hline
\end{tabular}

Source: personal collection.

In most cases, the main sources of broadcast signal were YouTube (18.9\%) and Facebook $(18.7 \%)$, while less than $5 \%$ of the parishes conducted technically independent broadcasts: either on their websites and/or based on their specific technical solutions (these were, e.g., surveillance cameras with audio transmission, use of local providers' services, or other websites). There was one parish which broadcast only sound, without the image. Occasionally, a video signal with a broadcast from another church was reported on the parish website. There were no reported uses of tools such as Periscope, Skype, Zoom, or other applications of this type, although they have been used in other countries (e.g., USA or the UK) (Xiong et al. 2020, p. 26; The Church of England 2020, p. 1; Zimmermann 2020).

The vast majority of parishes using social media applied their channels/profiles, although some also used private profiles belonging to their parishioners, parish groups (e.g., university chaplaincy centres), religious communities, societies, local Internet providers, media (including local Catholic media), and even local government units. Approximately half of the YouTube or Facebook broadcasts were split into both of these sources (i.e., the main broadcast took place on the YouTube channel, while the rebroadcast was published on Facebook). It should also be noted that the sample included parishes which had been active on Facebook and YouTube before the pandemic, but chose not to broadcast Masses from their church autonomously. 
Attention is drawn to the predominance of Facebook and YouTube social networking sites when choosing technical solutions for broadcasting, as well as the fact that many parishes have diversified their broadcasting access channels ${ }^{6}$.

4.3.4. The Frequency of Broadcast and the Geographical Location of Parishes (the Region of Poland)

The dioceses in which the most online Mass broadcasts were organised were the dioceses of Bielsko-Żywiec, Katowice, Gdańsk, and Warsaw-Praga. The research showed a statistically significant correlation $(p<0.002)$ between online Mass broadcasting and the region of Poland (Figure 1). The smallest number of broadcasts occurred in the northwestern and north-eastern parts, whilst the largest number occurred in central Poland.

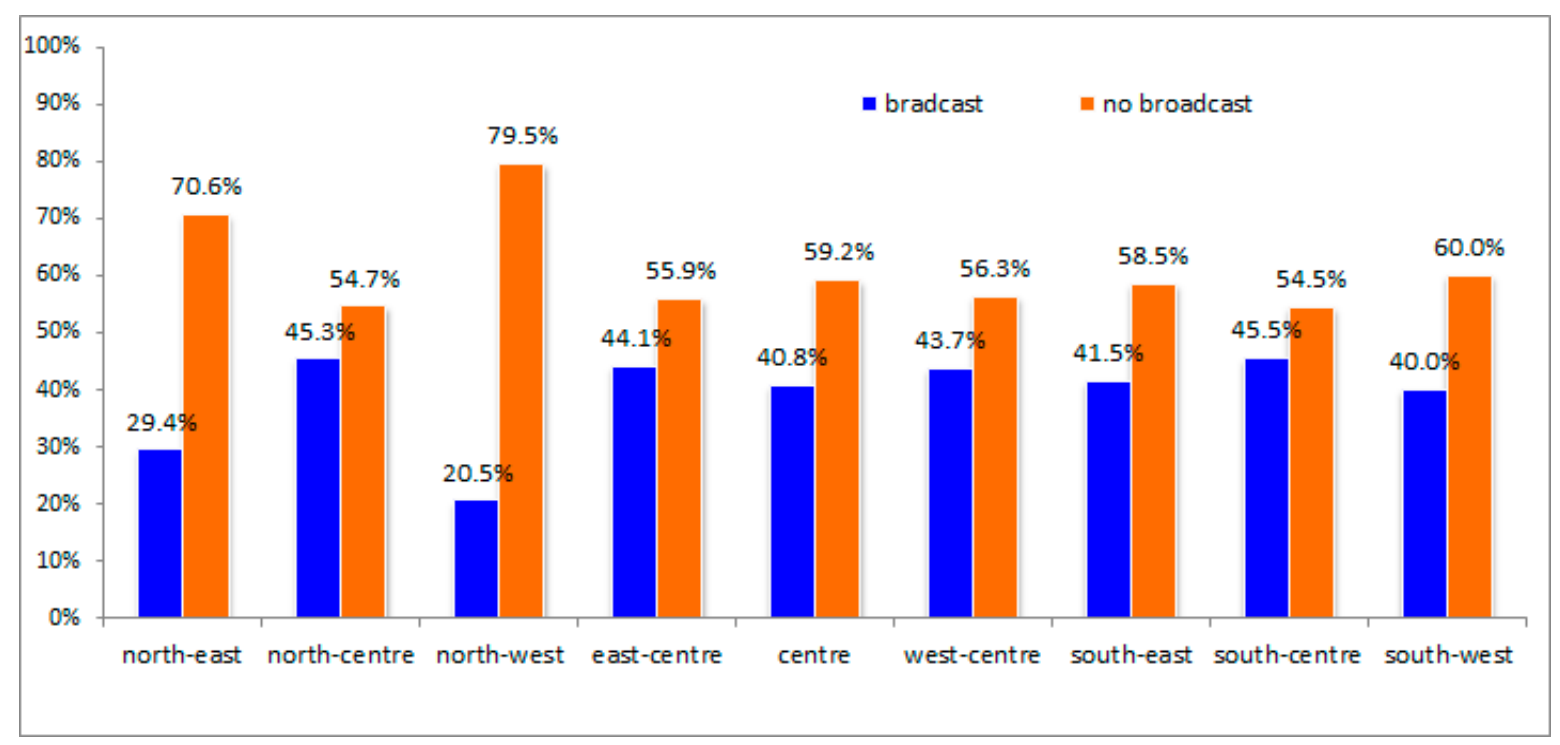

Figure 1. Online Mass broadcasting and geographical location of the parish (\%). Source: personal collection.

The reasons for such data distribution are ambiguous. One of the most important factors may be that the level of religiousness of Poles is much higher in the south-eastern regions than in the north-western parts of the country; this, in turn, is due to some historical circumstances, such as partitions or migrations (Sadłoń 2018, pp. 190-91).

This may also be related to access to modern communication technology facilities. As the authors of the National Broadband Plan report note, "There are clear differences in access to modern communication technology facilities between the eastern and western parts of the country, as well as between the northern and southern parts. This is mainly due to the geographical and demographic nature of Poland: the eastern and north-eastern areas of the country are mostly rural areas with low or very low population density and dispersed settlements. Despite intensive incentives from the state or local government units, in such circumstances, it is not cost-effective in the long term to invest in modern communication infrastructure, as maintenance costs are often high and exceed the potential profits from the investment" (The Council of Ministers of the Republic of Poland 2020, p. 14).

Another quite important factor appears to be the specific structure of dioceses in the north of Poland (especially in the north-eastern and north-western parts). In these dioceses, in places with relatively low population density, parishes cover vast areas despite a small number of believers. In many cases, one parish priest has three to five small rural churches or chapels to minister on Sundays. This makes broadcasting difficult to carry out

6 As regards YouTube broadcasts, the Polish Episcopal Conference Press Office informed that Google had abolished the requirement of having 1000 subscribers for parishes that wanted to broadcast on YouTube during the pandemic (this limit, however, only applies to broadcasts using mobile devices). Although this information was reposted by many websites, it has been officially confirmed by the Google Press Office in Poland (Biuro Prasowe KEP 2020a; ad/Stacja7 2020). 
from a purely technical point of view, combined with poor Internet access technology (few fibre-optic lines and poor mobile network coverage).

Yet another factor that may have determined the decision on broadcasting could be the digital communication indicator in a given parish, which can be measured by, e.g., whether it has its website and/or a social media profile (Sadłoń 2018, p. 50 and next (pages)). A comparison of these three indicators: the percentage of broadcasts in dioceses, the percentage of parishes which have their own websites, and the percentage of parishes which are active on social media, show the relationship between these variables (Table 2). The analysis of the data showed that there is a statistically significant relationship $(p<0.001)$ between having a website and conducting online Mass broadcasting.

Table 2. The correlation between the percentage of broadcasts in dioceses and the percentage of parishes having their own websites (recoded data).

\begin{tabular}{|c|c|c|c|c|c|c|c|c|}
\hline & & \multicolumn{6}{|c|}{ Percentage of Parishes Having Their Own Websites } & \multirow{2}{*}{ Overall } \\
\hline & & 40 and Less & $41-50$ & $51-60$ & $61-70$ & $71-80$ & 81 and More & \\
\hline \multirow{6}{*}{$\begin{array}{l}\text { Percentage of parishes } \\
\text { broadcasting online }\end{array}$} & 20 and less & - & - & $100.0 \%$ & - & - & - & $100.0 \%$ \\
\hline & $21-30$ & $11.1 \%$ & $22.2 \%$ & $33.3 \%$ & $22.2 \%$ & $11.1 \%$ & - & $100.0 \%$ \\
\hline & $31-40$ & - & $45.5 \%$ & $45.5 \%$ & - & $9.1 \%$ & - & $100.0 \%$ \\
\hline & $41-50$ & - & $12.5 \%$ & $25.0 \%$ & $12.5 \%$ & $37.5 \%$ & $12.5 \%$ & $100.0 \%$ \\
\hline & $51-60$ & - & - & $16.7 \%$ & $33.3 \%$ & $50.0 \%$ & - & $100.0 \%$ \\
\hline & 61 and more & - & - & - & - & - & $100.0 \%$ & $100.0 \%$ \\
\hline Total & & $2.4 \%$ & $19.5 \%$ & $34.1 \%$ & $12.2 \%$ & $19.5 \%$ & $12.2 \%$ & $100.0 \%$ \\
\hline
\end{tabular}

Source: compilation based on personal research and (Institute for Catholic Church Statistics 2020, pp. 36-39).

\subsubsection{The Frequency of Transmission versus Parish Size and Type}

There is a statistically significant difference $(p<0.001)$ between the parish size and Mass broadcasting - the larger the parish, the more often such activities were performed (Figure 2). Over $75 \%$ of the largest Polish parishes had their Sunday Mass broadcast, while for the smallest ones the percentage was $18.1 \%$. It is worth noting that the results in the group of parishes with an unknown number of believers is very close to the national average.

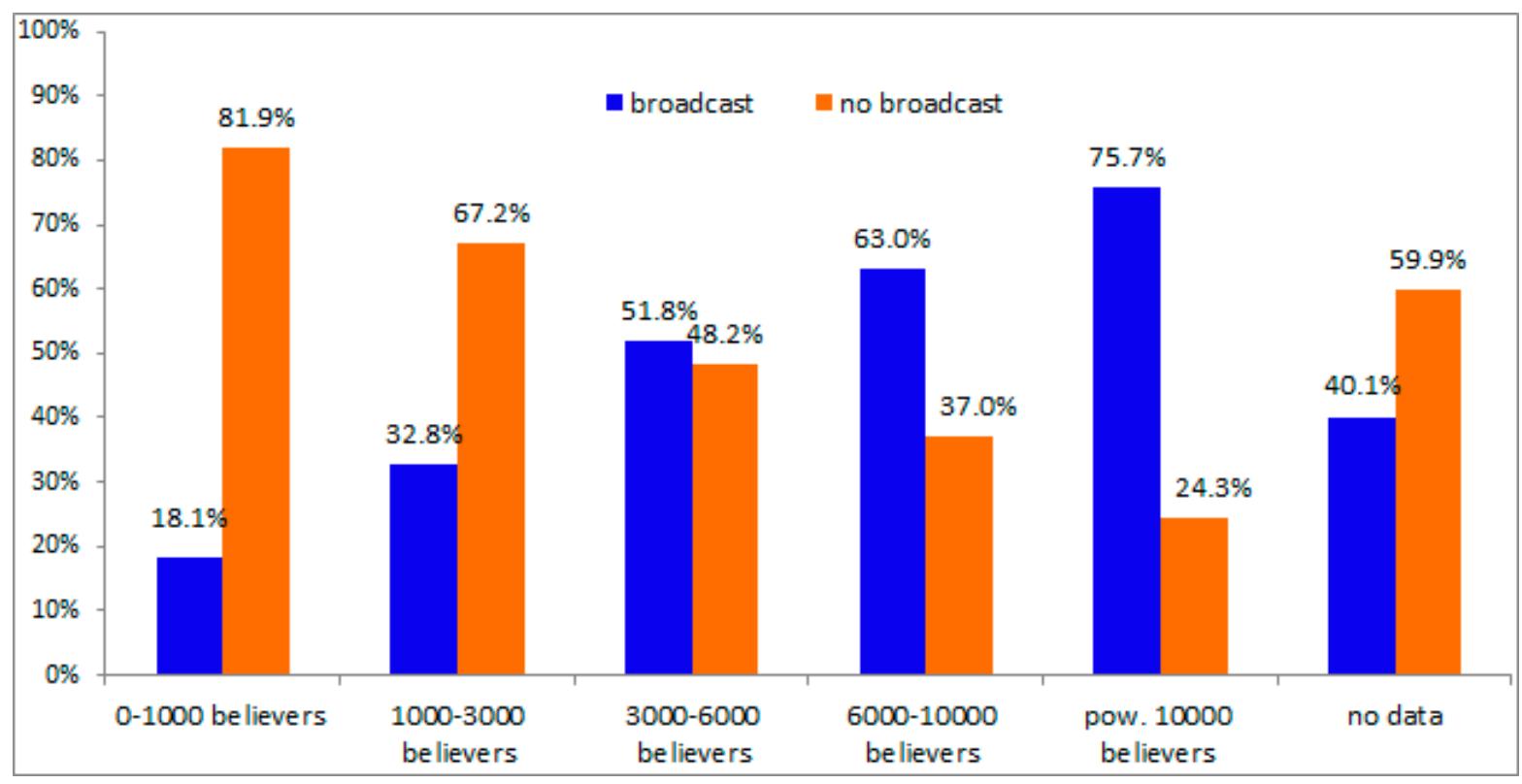

Figure 2. Online Mass broadcast and the size of parish. Source: personal collection.

A similar correlation was observed between urban and rural parishes-the latter carried out much less frequent Mass broadcasts online (Figure 3). 
Such a research result is due to several factors. One of them is undoubtedly a purely technical issue. Parishes with more than 10,000 believers are usually located in large cities, where IT infrastructure is much more advanced and the Internet connection has much greater capacity. Besides, with a large number of parishioners, people who have the relevant knowledge and are able to share it with the priests can be more easily involved in parish life. Moreover, in rural parishes, far from large urban centres, the population age average is often higher than in the city, and the popularity of the Internet is lower (Sadłon 2018, pp. 190-94). Television and the radio are more popular, so this group of believers was probably more interested in broadcasts via these media types (it is also relevant that most dioceses have their own local radio stations, and many dioceses broadcast for example from cathedral churches). The networking of rural parishes is far less supported by electronic means of communication than in cities. Rural parishes more rarely manage their websites, social media profiles, or publish the parish press (Sadłoń 2013, pp. 39-40).

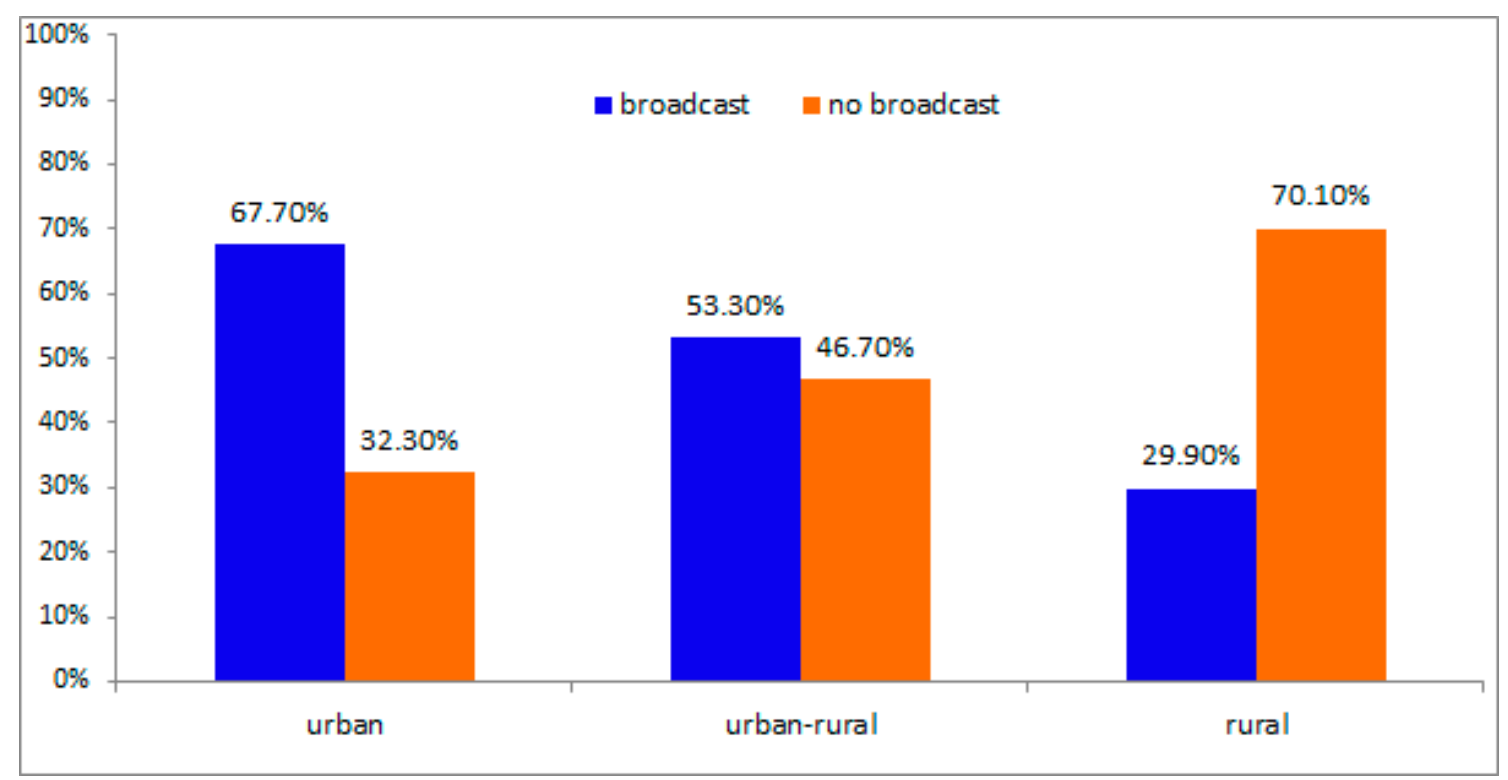

Figure 3. Online Mass broadcast and the type of parish. Source: personal collection.

It should also be noted that urban and rural parishes function in different ways. In rural parishes, the involvement of the faithful in parish life is greater as regards personal help. The sense of bond with the parish also plays a greater role, although parishioners in rural areas have a poorer opinion of their parish priests in terms of homily, church decoration, or liturgy preparation. Nevertheless, rural parish priests enjoy greater trust from their parishioners. In cities, on the other hand, the faithful have less influence on their parish and are more often unwilling to have it. In terms of networks, rural parishes rely almost entirely on cognitive networks; the proportion of behavioural networks is very low. The faithful usually know their parish priest, although they rarely seek his help in need. As a result, the level of positive emotional/spiritual connection with the parish and the sense of belonging to the parish are much higher in the countryside than in the city, and they are embedded in the local dimension rather than the religious one (Sadłoń 2013, pp. 39-46; Sadłoń 2018, pp. 190-94).

It seems interesting that there is a statistically significant relationship $(p<0.001)$ between the type of parish (conventual or diocesan) and online Mass broadcasting (Figure 4). Conventual parishes did this much more often than diocesan ones $(68.6 \%$ and $38.9 \%$ respectively). This may be because the charisms of some religious orders involve the apostolate through media, e.g., the Society of St. Paul the Apostle. Other religious congregations have also adapted to the contemporary teaching of the Church and their statutes include presence of consecrated persons in the field of social communications (John Paul II 1996, 
p. 99). The Conferences of Major Superiors of Male and Female Religious Orders in Poland are very active. Before the pandemic, female religious orders alone had already carried out evangelisation through the media on about 500 websites and about 400 Facebook and Twitter accounts (The Conference of Major Superiors of Women Religious Orders 2019).

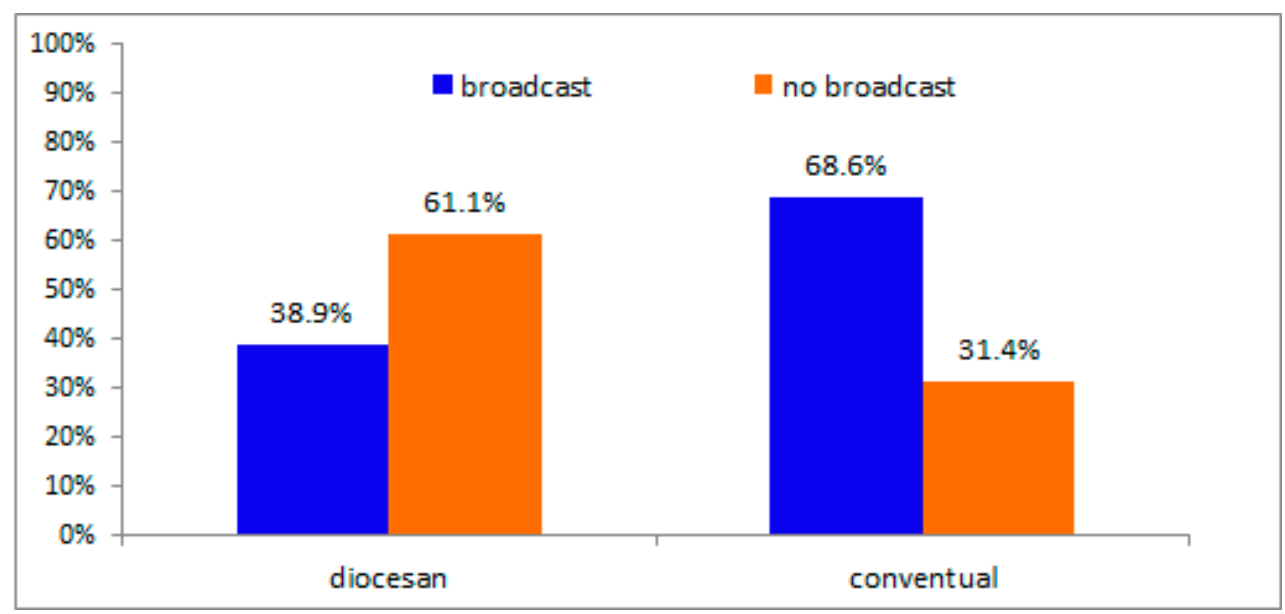

Figure 4. Online Mass broadcast and the type of parish. Source: personal collection.

This statistically significant dependence $(p<0.001)$ in favour of conventual parishes may also have been caused by the increased number of order-affiliated people supporting their parish communities in liturgical life. A large number of religious orders have their generalates in Rome, it is therefore possible that inspiration on how to stream Mass came from there (Fossati 2020).

4.3.6. The Frequency of Broadcasting versus the Dominicantes/Communicantes Indicators, the Proportion of Priests to Catholics in a Given Diocese, and the Participantes Indicator

In 14 out of 41 Roman Catholic dioceses examined, the bishops encouraged parish priests to conduct online broadcast-e.g., the bishop of Drohiczyn suggested in his ordinance of 3 April 2020: "If parish priests can do so, I also encourage them to organise broadcasts from parish churches and thus invite their parishioners to form a spiritual community united by prayer and contemplation on the most important mysteries of our faith." The curia of Radom provided a guide on its website explaining how to prepare an online broadcast. Many dioceses had lists of parish broadcasts published on their websites. Research has shown that in the dioceses where bishops directly encouraged parish priests to broadcast from their parishes, the average percentage of broadcasts was higher $(46 \%)$ than in those in which there were no such incentives $(38 \%)$. This factor was not the dominant one, and certainly not the only one, but it can be assumed that the bishops' decision to officially support online broadcasting was one of the triggers of this form of evangelisation. This phenomenon, on the one hand, confirms the importance of the decision and the stimulus from the Church authorities regarding forms of religious worship limited to online broadcasting; on the other hand, due to the very limited scope $(1 / 3)$ of such decisions of encouragement, it indicates the low level of bishop awareness as regards the importance of this form of evangelisation.

The analysis also included the results of internal research and the participantes indicator based on the data from the Institute for Catholic Church Institute for Catholic Church Statistics (2020), measuring the activity of laypeople in parishes (according to individual dioceses). It turns out that there is a statistically significant correlation between these indicators, which is revealed in the fact that dioceses with the lowest broadcast rates also displayed the lowest level of involvement of laypeople. At the same time, dioceses that are active as regards the broadcasting of Mass from parishes are also characterised by a relatively high rate of participantes. 
As far as the dominicantes indicator is concerned, the analysis showed a significant correlation $(p<0.001)$ between the level of this indicator and the broadcasts: most of them were carried out in dioceses with a very high indicator, i.e., over 50 (here the broadcasting was carried out by almost $50 \%$ of parishes) and in dioceses with an average level of dominicantes, i.e., between 36 and 40 (broadcasting in $51.7 \%$ of parishes). A very similar situation was found in the case of the communicantes indicator: dioceses with high (19-20) and medium (15-18) levels of this indicator broadcasted Mass more often than others$45.2 \%$ and $39.2 \%$ respectively. To some extent, such coherence of these data may appear surprising, because the dominicantes indicator and, most importantly, the communicantes indicator do not depend on the level of activity of parish priests. There is a significant likelihood of reversing the conclusion presented in the next paragraph: since parish priests with high levels of these indicators are aware of the religious activity of their parishioners (based on parish practice and ICCS research), they may have wanted to maintain these activities and thus avoid leaving the faithful without the opportunity to participate in the remote liturgy, but in the local community. This is confirmed by the proportionality of the number of broadcasts in parishes in which there were medium and low dominicantes and communicantes indicators. In this case, we may consider this situation to be a result of the involvement of active parishioners, and treat the broadcasts as their initiatives. However, this factor remains secondary (if not negligible) to the initiating role of the clergy (both in relation to participantes and online broadcasts).

The study also checked whether there was a link between the broadcasting of Sunday Eucharist during the pandemic and the number of priests per Catholics, which is one of the indicators measured in the annual reports of the Institute for Statistics of the Catholic Church (Figure 5). It strikes as a surprising fact that the dioceses with the lowest number of priests per Catholics had relatively the most broadcasts (56.7\%). Perhaps it was precisely the shortage of priests that was the reason why, especially at that time, the intention was to take care of the faithful and to build a virtual community. The lower level of contact with the parishioners may also be an issue here, with the introduction of online liturgy not simply to be treated as a substitute for what used to be, but as an opportunity for something more which had not previously been possible. At the same time, also the dioceses with the highest percentage of priests per Catholics broadcast to a large extent (47.5\%). In this case, the economic scale factor probably had an impact; moreover, due to the better personal relationship with the parishioners, the situation increased the level of responsibility for the familiar community and strengthened the sense of duty to consolidate this through a shared liturgy broadcast from the parish.

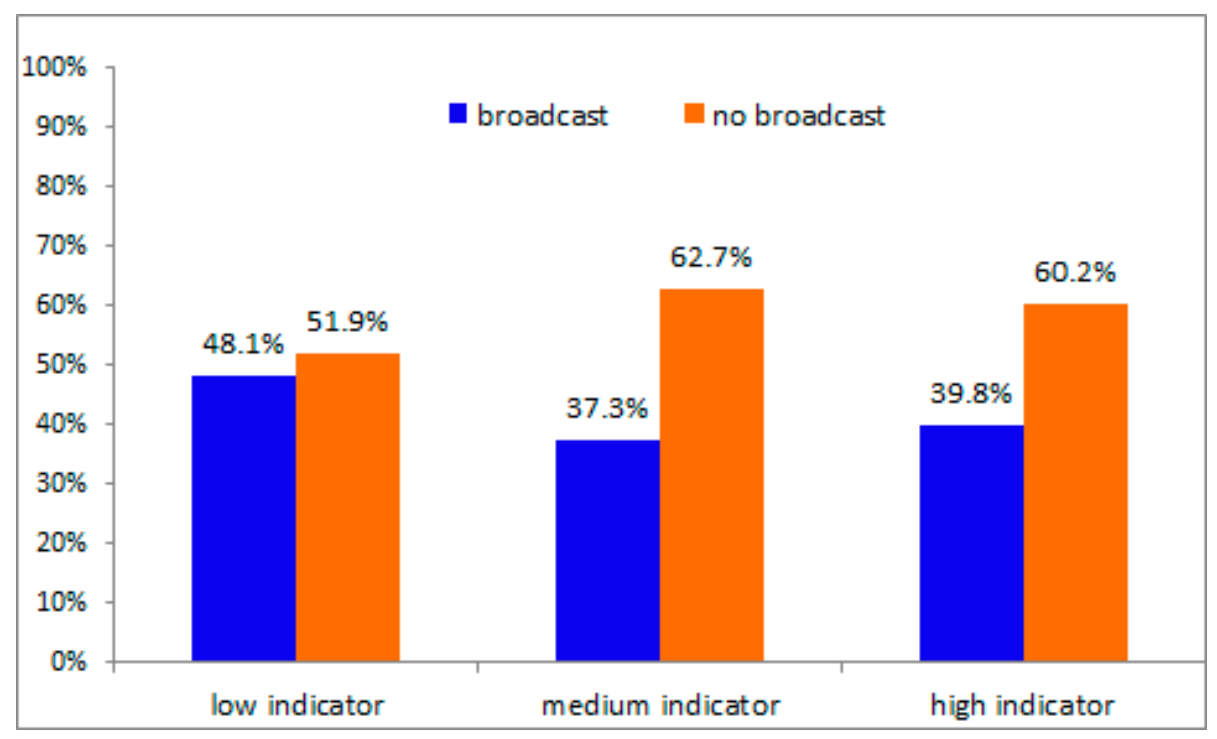

Figure 5. The relationship between the number of priests per believers (indicator size) and Mass broadcasting. Source: personal collection. 


\section{Final Comments and Conclusions}

The latest document by the Congregation for the Clergy "The pastoral conversion of the Parish community in the service of the evangelising mission of the Church" remarks that "the territorial configuration of the Parish, however, must confront a peculiar characteristic of our contemporary world, whereby increased mobility and the digital culture have expanded the confines of existence" (Congregation for the Clergy 2020, p. 8). Additionally, the first period of the COVID-19 pandemic radically affected the activities of parishes in Poland, as virtually all of their activities were transferred to the Internet, including parish Masses. The words of Pope John Paul II proved to be current: "the parish is still a major point of reference for the Christian people, even for the non-practicing" (John Paul II 1997, p. 67). The pastoral assumption was to spiritually unite the faithful with the celebrated liturgy and, indeed "the parish is a beacon that radiates the light of the faith and thus responds to the deepest and truest desires of the human heart, giving meaning and hope to the lives of individuals and families" (Benedict XVI 2006). It also turned out that despite the undoubtedly progressive secularisation of the Polish society, "the parish is not an outdated institution; precisely because it possesses great flexibility, it can assume quite different contours depending on the openness and missionary creativity of the pastor and the community" (Francis 2013, p. 28). Online live-streaming of the Holy Mass during the first phase of the COVID-19 pandemic in Poland has become a spiritual space for reaching out to the roots of the Church. Whether it showed a truly deeply religious face of the Polish society, whether it resulted from the fear of death and the subjective need to secure a chance for eternal life, or whether it was related to the facilitation of participation in the online liturgy (participation without the necessary focus and involvement in the broadcast), remains an open question, which requires detailed and representative research on the level of the audience/Polish Catholics.

During this time, online live-streamed Mass was not only intended to provide a common prayer mainly for the sick and the elderly, who cannot go to church. Instead, the COVID-19 pandemic created a new requirement to provide broadcast to all the faithful locked indoors. The changes associated with the general lockdown resulted in all celebrations being transferred to the Internet and other media. Thus, the belief that "the latest technological developments are also capable of successfully contributing to making humanity and the world better, happier" proved to be justified (Misztal 2020, p. 105).

The presented media-pastoral study of the implementation of Mass online broadcasting in Poland during the first phase of the COVID-19 pandemic showed its dynamic development, not seen before in the history of the Church. The credibility of the empirical research also lies in the fact that it did not come from the self-declarations of those in charge of broadcasting, as it was collected during the first phase of the pandemic directly from the websites of the parishes and communities that ran them.

At the "see" methodology stage it was shown that the restrictions imposed in connection with the pandemic accelerated the digitalisation and mediatisation of the Catholic Church in Poland, with $40.8 \%$ of Polish parishes broadcasting Mass online. This very high percentage of parishes overcame difficulties concerning technology and competence to be close to their faithful. It is also important to take into account the fact that parishes were challenged to start broadcasting practically overnight, without warning, without time for preparation. Many parish priests, especially elderly ones, were unable to face such a challenge. In these situations, younger priests or lay parishioners came to the rescue. The joint and considerable effort that was made to ensure that the faithful were able to attend Mass broadcasts from local parishes is undoubtedly visible. This shows both the attachment to the local community of the faithful as well as the sense of responsibility for it. At that time there were a huge number of nationwide broadcasts of the liturgy (television, the Internet), and access to them was much easier than to local broadcasts (mainly via the Internet and social media). Since there were no restrictions for the participants of online liturgy, one all-day (Sunday) package of such broadcasts, intermediated by various media 
(the radio, television, and the Internet), would be sufficient for the whole of Poland. Despite this, individual parishes made an effort to create their own broadcasts.

At the "judge" stage, the rapid development of the legislation of the Catholic Church in Poland on the broadcasting of Mass and services was presented. Previous pastoral provisions had not foreseen a situation in which believers would be completely confined to their homes. There was no thorough theological and pastoral reflection, but each diocese issued a dispensation and encouraged spiritual communication, indicating Mass broadcasts in the traditional media and on the Internet as a tool to facilitate this.

At the "act" stage, it was noted that there is a noticeable correlation between the percentage of parishes broadcasting the Sunday Eucharist and such variables as: geographic location (which may be related to the quality of IT facilities), parish size (the larger the parish, the higher the percentage of broadcasts), and parish type (urban parishes broadcast more often than urban-rural ones, and much more often than rural ones). Among the largest Polish parishes, more than $75 \%$ provided a broadcast of Sunday Masses; they responded with a new pastoral approach towards the faithful. Conventual parishes broadcast more often than diocesan ones. It can also be said that there was a correlation between the frequency with which parishes in a given diocese had a website and the frequency with which they broadcast. There is also a statistically observable correlation between the broadcast and the following variables: the dominicantes/communicantes/participantes indicators, and the ratio of the number of priests to the number of Catholics in a given diocese. These figures showed that the communities which had attended Sunday Mass until the pandemic (dominicantes) and received Holy Communion (communicantes), became involved in the organisation of the broadcast even more actively.

Along with the last factor facilitating the implementation of the broadcast-a smaller number of believers per one priest-all these variables form a multidimensional matrix which provides an unambiguous evaluation of the components influencing the implementation of broadcasting and, as a result, greater opportunities for parishioners to participate in Mass in their parishes, to maintain the local community, and to potentially continue caring for it after restrictions surrounding social distancing have been removed.

At the "review" stage, the analysis of the assumptions and implementation of Mass broadcasting showed the need to start a theological discussion on the new opportunities for online participation in Mass. This stage shows that there is certainly a need to deepen the debate on the spiritual communion and on how to experience participation in the broadcast service; these topics have not yet been widely present in the religious education of the faithful. The general indications to date (the Mass liturgy must not be celebrated for the sole purpose of broadcast and therefore the only form allowed is direct broadcast, never re-broadcast) have been successfully implemented. No encouragement to watch a re-broadcast was observed during the research, but the message was clear: Mass is to be celebrated always at the time and the direct broadcast channel precisely specified, and with the encouragement to participate in a common live celebration.

We consider this approach legitimate since we stand for the harmonious cooperation and fusion of Science and Theology. In its research, theology needs to build on the findings of other scientific disciplines, and they need theology to stand "in front of the Mystery" (Magnin 2013). The aims (among other things) of theology are the formulation of reasons of faith and motives of hope, i.e., rational and objectively valuable arguments, necessary for the dialogue with contemporary culture, world religions, and visions of human life; the examination of the objective value of these reasons and motives; and finally their defence. Thus, theology is a frontier discipline, with windows open to the humanities-history, philosophy, linguistics, psychology, sociology, ethnology, and the like. On the one hand, it assimilates what people outside know in anthropology, philosophy, history, social sciences, and mathematical and natural sciences. On the other hand-it invites them inside to think in the light of Revelation (Seweryniak 2010, pp. 12-13).

Depending on the object of study, reason uses different methods adapted to that object. Rationality is one, but it takes many forms; similarly, science is multiform since each science 
has its object and specific method. Modern scientific reason carries with it a question that points beyond itself and the possibilities of its methodology. It must accept the rational structure of matter and the correspondence between the spirit and the rational structures of nature as a fact on which it must base its methodology. The question of why this must be so is fundamental —and the natural sciences must pass this on to other methods and levels of thought: philosophy and theology. The presence of theology and theologians at the heart of university life and the dialogue this presence enables with other disciplines help promote a broad, analogical, and integral view of intellectual life (International Theological Commission 2011, n. 68, p. 84). We realise that our article escapes a clear assignment to a particular academic discipline. We consider this approach to be entirely legitimate because of the multifaceted nature of reality under study. It cannot be explained by reducing the research approach to what is known, certain, safe, and established.

It should be added that when broadcasting Mass online, on a large scale and using simple technical tools, it is difficult to maintain the formative dimension of the broadcast, mentioned in the 2017 Directory quoted earlier. It can even be said that the massive scale of broadcasting means that communication aspects were chosen at the expense of exclusively understood formation, implemented through selected "exemplary" celebrations from the most beautiful churches. The pandemic came suddenly; there was no time for both spiritual and media preparation. No-one was criticised for the quality of their Internet connection, nor for the fact that the cameras were not fully set for liturgy. Efforts were made to overcome technical problems. Using Internet connections, the faithful could stay together in prayer and not feel abandoned by their parishes. Although there was no time to reflect on mediatisation in the process of evangelisation with its pre-evangelisation (preparatory) function, the aim was to make the mediatisation of religion fulfil its pro-evangelisation (supporting) function.

It is also worth remembering that in pre-pandemic practice, the Church recommended personal participation in the liturgy. This was caused by fears of the virtualisation of communities and the faithful freeing themselves too easily from personal participation. However, when drastic restrictions caused by the threat to health and life were introduced, a pro-media attitude prevailed in many cases, expressed both by the large-scale and-as analysed here- the grassroots broadcasting of the Eucharist on a sub-local scale. This had another additional dimension: that of strengthening interpersonal ties at a parish level. For many people the possibility to see "their" pastors and "their" parish church on a computer or smartphone screen was very important, and this gave them a much greater sense of community than following a broadcast on the radio or television. Thus, the grassroots implementation of Mass broadcasting became an emanation of the social dimension of these platforms, which additionally took advantage of all the features of this type of media: after all, apart from the reception of the message, it was also possible (according to the recommendations of the Church) to communicate with other participants of the event, comment on it together, or simply support each other after it ended.

From a communication point of view, we consider another aspect to be quite important. If we look at faith and religion as a process of communication between people and God, we have to say that this communication takes place in a community. It is spiritual unity, with sacraments, which are a visible sign of invisible grace, playing an important role. For this reason, the minister of sacraments also acts as an intermediary in this communication. While the Church remains consistently of the opinion that sacraments are impossible in cyberspace, the experience of the pandemic has caused its teaching to shift more emphasis than before on spiritual forms of direct communication between people and God (although still within the Church community), such as perfect contrition or spiritual communion. Broadcasts undoubtedly facilitate spiritual communication with God and the praying community by visualizing (or at least providing a sound layer) of actual events taking place in the here and now, in actual places with which the viewer/participant feels connected. Nevertheless, it should be noted that there is another element in this process of communication: people who handle technical aspects of broadcast, Internet service 
providers, camera operators, etc. Therefore, a positive evaluation of the scale at which the Holy Mass was broadcast in Poland will certainly involve providing technical, professional, but also theological support to its organisers. A particularly urgent task is to deepen research into the issue of faith virtualisation, with its challenges and threats. An additional field of research will involve comparative studies from the first period of the pandemic with the next period. The so-called longitudinal research may serve to understand the development of the mediatisation of religion and the factors influencing contemporary pastoral activities and the reaction of the Church.

Furthermore, research has shown that due to the outbreak of the pandemic, the processes of mediatisation of religion in Poland in relation to the Roman Catholic faith have intensified. The data for 2016 showed that only a few parishes had profiles on social media. Meanwhile, our study has shown that Facebook and YouTube were the preferred broadcast channels for Sunday Eucharist. One can therefore venture the hypothesis (to be verified in subsequent studies) that the outbreak of the pandemic has mobilised parishes to intensify their presence on social media. Thus, the processes of mediatisation in the Church in Poland as regards opening new channels of communication between priests and parishioners have become more dynamic. Similarly, in 2016, surveys conducted among Internet users showed that only $15 \%$ of them visited religious websites, mainly in order to "complement offline religious activity, e.g., praying, participating in a service" (CBOS 2016). The increased online activity of parishes has likely resulted in a significant rise in the number of people using Internet broadcasts, not only during the pandemic. For young people in particular, the digital world is an important part of their reality and the Church already recognises the importance of using social media for evangelisation as well. As the Polish Bishops' Conference spokesman, Fr Leszek Gęsiak, pointed out, "the space of social media is not yet fully exploited by the Church" (Święciński 2020).

It should also be emphasised, however, that once the restrictions stopped, a "step back" could be observed. Many parishes abandoned broadcasting, and bishops withdrew their dispensations and encouraged personal participation in Sunday Mass. As the pandemic will probably return in subsequent waves (as is the case in the autumn of 2020), the solutions developed by dioceses and parishes will be implemented in the long term. This also entails the need to continuously improve the media competence of both the broadcasters (priests and laypeople helping to organise broadcasting of Masses and other services) and the recipients themselves. The Internet space, especially social media, can be used not only for evangelisation, but also for religious education, community experience, and building or maintaining ties within the community (for example, parish communities, which can only survive in this way during the pandemic). The large-scale digital transformation that has taken place in the Church in Poland in recent months is a long-lasting asset that should be used in "normal" times, not only to broadcast Masses, but also to carry out various prayer, pastoral, cultural, charitable, and educational initiatives (Królak 2020).

Author Contributions: Conceptualization, B.P., A.A., A.K., M.S. and A.J.-G.; methodology, B.P., A.A., A.K., M.S. and A.J.-G.; formal analysis, B.P.; data curation, B.P. and A.A.; writing-original draft preparation, B.P., A.A., A.K., M.S. and A.J.-G.; writing-review and editing, B.P., A.A., A.K., M.S. and A.J.-G.; visualization, B.P. All authors have read and agreed to the published version of the manuscript.

Funding: This research received no external funding.

Conflicts of Interest: The authors declare no conflict of interest.

\section{References}

ad/Stacja7. 2020. Google znosi wymóg 1000 subskrypcji kanałów transmitujacych Msze. Available online: https://stacja7.pl/z-kraju/ google-znosi-wymog-1000-subskrypcji-kanalow-transmitujacych-msze (accessed on 13 November 2020).

Adamski, Andrzej. 2012. Media w Analogowym i Cyfrowym Świecie. Warszawa: Elipsa. 
Adamski, Andrzej. 2015. Media as the intersphere of human life. Another view on the mediatization of communication theory. In Megatrends and Media. Media Farm -Totems and Taboo. Edited by Dana Petranová and Slavomír Magál. Trnava: Faculty of Mass Media Communication University of Ss. Cyril and Methodius in Trnava, pp. 16-39.

Adamski, Andrzej. 2019. Sacrum in the Digital World: The Processes of Remediation on the Example of the Liturgical Books of the Catholic Church. In Remediation: Crossing Discursive Boundaries. Central European Perspective. Edited by Bogumiła Suwara and Mariusz Pisarski. Berlin-Bratysława: Peter Lang/Veda Publishing House, pp. 227-48.

Adamski, Andrzej, and Grzegorz Łecicki. 2016. Theology and media studies: Interdisciplinarity as a platform for joint reflection on the media. Studia Medioznawcze 1: 11-19. [CrossRef]

Ambroziak, Łukasz, Adam Czerwiński, Katarzyna Dębkowska, Jacek Grzeszak, Urszula Kłosiewicz-Górecka, Jan Strzelecki, Anna Szymańska, Ignacy Święcicki, Piotr Ważniewski, and Katarzyna Zybertowicz. 2020. Internet-Strategiczna infrastruktura w czasach pandemii. Tygodnik Gospodarczy PIE 12: 7-9.

Ampuja, Marko, Juha Koivisto, and Esa Väliverronen. 2014. Strong and Weak Forms of Mediatization Theory. A Critical Review. Nordicom Review 36: 111-23. [CrossRef]

Andok, Mónika, and Fanni Vígh. 2018. Religious communities' digital media use: A Hungarian case study. In Believe in Technology: Mediatization of the Future and the Future of Mediatization. Edited by Mihaela-Alexandra Tudor and Stefan Bratosin. Les Arcs: IARSIC France, pp. 378-92.

Archidiecezja Krakowska. 2020. Jak Dobrze Przeżyć Mszę św. za Pośrednictwem Mediów? March 13. Available online: https: / / diecezja.pl/aktualnosci/jak-dobrze-przezyc-msze-sw-za-posrednictwem-mediow / (accessed on 17 November 2020).

Asp, Kent. 1990. Medialization, media logic and mediarchy. Nordicom Review 11: 47-50.

Bekkering, Denis J. 2018. American Televangelism and Participatory Cultures. Fans, Brands, and Play with Religious "Fakes". Cham: Palgrave Macmillan.

Benedict XVI. 2006. Homily during a Pastoral Visit to Our Lady Star of Evangelization Parish of Rome. Available online: http://www. vatican.va/content/benedict-xvi/en/homilies/2006/documents/hf_ben-xvi_hom_20061210_star-evangelization.html (accessed on 1 October 2020).

Benedict XVI. 2007. Post-Synodal Apostolic Exhortation "Sacramentum Caritatis" of the Holy Father Benedict Xvi to the Bishops, Clergy, Consecrated Persons and the Lay Faithful on the Eucharist as the Source and Summit of the Church's Life and Mission. Available online: http:/ /w2.vatican.va/content/benedict-xvi/en/apost_exhortations/documents/hf_ben-xvi_exh_20070222 _sacramentum-caritatis.html (accessed on 1 October 2020).

Berger, Teresa. 2013. @Worship. Exploring Liturgical Practices in Cyberspace. Questions Liturgiques/Studies in Liturgy 94: 266-86. [CrossRef]

BF. 1988. Breviarium Fidei. Wybór Doktrynalnych Wypowiedzi Kościoła. Edited by Stanisław Głowa and Ignacy Bieda. Poznań: Księgarnia Św. Wojciecha.

Biuro Prasowe KEP. 2020a. Google ułatwia Parafiom Transmisje na YouTube. Available online: https:/ / episkopat.pl/google-ulatwiaparafiom-transmisje-na-youtube (accessed on 1 October 2020).

Biuro Prasowe KEP. 2020b. Rzecznik Episkopatu o Przeżywaniu TRANSMISJI Mszy Świętych. Available online: https: / episkopat.pl/ rzecznik-episkopatu-o-przezywaniu-transmisji-mszy-swietych/ (accessed on 21 November 2020).

Bratosin, Stefan. 2016. La médialisation du religieux dans la théorie du post néo-protestantisme. Social Compass 63: 405-20. [CrossRef]

Bratosin, Stefan. 2020. Mediatization of Beliefs: The Adventism from "Morning Star" to the Public Sphere. Religions 11: 483. [CrossRef]

Bretthauer, Berit. 1995. The challenge of televangelism. Peace Review 7: 73-79. [CrossRef]

Britannica. 2013. Young Christian Workers. Available online: https://www.britannica.com/event/Young-Christian-Workers (accessed on 3 September 2020).

Butkiewicz, Magdalena, and Grzegorz Łęcicki. 2018. Ewolucja i specyfika teologii mediów w systemie nauk teologicznych i nauk o mediach. In Teologia Środków Społecznego Przekazu w Naukach o Mediach. Edited by Jerzy Olędzki. Warszawa: Wydawnictwo UKSW, pp. 97-120.

Campbell, Heidi. 2004. Challenges created by online religious networks. Journal of Media and Religion 3: 81-99. [CrossRef]

Campbell, Heidi. 2005. Making Space for Religion in Internet Studies. The Information Society 21: 309-15. [CrossRef]

Campbell, Heidi A. 2010. When Religion Meets New Media. London and New York: Routledge.

Campbell, Heidi A., ed. 2013. Digital Religion. Understanding Religious Practice in New Media Worlds. New York: Routledge.

Campbell, Heidi A., and Michael W. DeLashmutt. 2014. Studying Technology and Ecclesiology in Online Multi-Site Worship. Journal of Contemporary Religion 29: 267-85. [CrossRef]

CBOS. 2016. Korzystanie z Religijnych Stron i Portali Internetowych. 93 vols. Komunikat z badań. Warszawa: CBOS, Available online: https://www.cbos.pl/SPISKOM.POL/2016/K_093_16.PDF (accessed on 21 November 2020).

Chmielewski, Mirosław. 2019. Edukacja medialna-Rola w Kościele i kierunki rozwoju (Media literacy-The role in the Church and the trends of development). Biuletyn Edukacji Medialnej 1: 11-30.

Chmielewski, Mirosław. 2020. Media Education and the New Evangelization Part One: Media Components and Challenges. Verbum Vitae 37: 407-25. [CrossRef]

Code of Canon Law. 1983. Vaticano: Libreria Editrice Vaticana.

Concordat. 1998. Concordat between the Holy See and the Republic of Poland, signed in Warsaw on 28 July 1993 . Dziennik Ustaw. 1998/51, poz. 318. Available online: https:/ / pracownik.kul.pl/files/26914/public/CONCORDAT.pdf (accessed on 8 April 2021). 
Congregation for the Clergy. 2020. Instruction "The Pastoral Conversion of the Parish Community in the Service of the Evangelising Mission of the Church". Available online: https://press.vatican.va/content/salastampa/en/bollettino/pubblico/2020/07/20/2 00720a.html (accessed on 13 November 2020).

Couldry, Nick. 2008. Mediatization or mediation? Alternative understandings of the emergent space of digital storytelling. New Media $\mathcal{E}$ Society 10: 373-91.

Couldry, Nick, and Andreas Hepp. 2013. Conceptualising Mediatization: Contexts, Traditions, Arguments. Communication Theory 23: 191-202. [CrossRef]

Cylka, Tomasz. 2020. Koronawirus. Dominikanie zamykają kościół. W pozostałych—50 osób w środku i włączone głośniki na zewnątrz. Tak będą wyglądać niedzielne msze. Gazeta Wyborcza. March 14. Available online: https://poznan.wyborcza.pl/ poznan/7,36001,25789540,koronawirus-50-osob-w-kosciele-i-wlaczone-glosniki-na-zewnatrz.html (accessed on 15 March 2020).

Cymanow-Sosin, Klaudia. 2020. Wyznaczniki dziennikarstwa preewangelizacyjnego-Kompozycja standardów w oparciu o model 4P. Kultura-Media-Teologia 41: 175-91. [CrossRef]

Czaja, Andrzej, and Wojciech Lippa. 2020. Decree of the Bishop of Opole of 20 April 2020 (No. 16/2020/A/KNC-K). Available online: https:/ / diecezja.opole.pl/index.php/homepage/aktualnosci/2554-nowy-dekret-biskupa-opolskiego (accessed on 2 November 2020).

Dębkowska, Katarzyna, Urszula Kłosiewicz-Górecka, Filip Leśniewicz, Anna Szymańska, Ignacy Święcicki, Piotr Ważniewski, and Katarzyna Zybertowicz. 2020. Nowoczesne Technologie w Przedsiębiorstwach Przed, w Trakcie i po Pandemii COVID-19; Warszawa: Polski Instytut Ekonomiczny. Available online: https:/ / pie.net.pl/wp-content/uploads/2020/06/PIE-Raport_Nowoczesne_ technologie.pdf (accessed on 15 November 2020).

Denson, Shane. 2011. Faith in Technology: Televangelism and the Mediation of Immediate Experience. Phenomenology E Practice 5: 93-119.

Deuze, Mark. 2011. Media Life. Media, Culture \& Society 33: 137-48.

Diekema, David A. 1991. Televangelism and the mediated charismatic relationship. The Social Science Journal 28: 143-62. [CrossRef]

Dobrołowicz, Michał. 2020. Sposób Kościoła na pandemię. Spowiedź odbywa się na parking. April 10. Available online: https:/ / www.rmf24.pl/raporty/raport-swieta/najnowsze-fakty/news-sposob-kosciola-na-pandemie-spowiedz-odbywa-siena-parkingu,nId,4432388 (accessed on 15 May 2020).

Drag, Katarzyna. 2020. Revaluation of the Proxemics Code in Mediatized Communication. Social Communication 6: 93-105. [CrossRef]

Draguła, Andrzej. 2009. Eucharystia Zmediatyzowana. Teologiczno-Pastoralna Interpretacja Transmisji Mszy Świętej w Radiu i Telewizji. Zielona Góra: Wydawnictwo Vers.

Draguła, Andrzej. 2020a. Modlitwa, nie “oglądanie”. Instrukcja obsługi transmisji Mszy świętej. Więź. March 14. Available online: http:/ / wiez.com.pl/2020/03/14/chodzi-o-modlitwe-a-nie-ogladanie-instrukcja-obslugi-transmisji-mszy-swietej (accessed on 17 November 2020).

Draguła, Andrzej. 2020b. Powrót na Mszę, czyli kłopoty z dyspensą. Więź. June 3. Available online: http://wiez.com.pl/2020/06/03 /powrot-na-msze-czyli-klopoty-z-dyspensa/\#_ftn1 (accessed on 17 November 2020).

Drozdowski, Rafał, Maciej Frąckowiak, Marek Krajewski, Małgorzata Kubacka, Ariel Modrzyk, Łukasz Rogowski, Przemysław Rura, and Agnieszka Stamm. 2020. Życie Codzienne w Czasach Pandemii. Raport z Pierwszego Etapu Badań. Poznań: University of Adam Mickiewicz.

European Commission. 2020. Commission and European Regulators Calls on Streaming Services, Operators and Users to Prevent Network Congestion. March 19. Available online: https:/ / ec.europa.eu/digital-single-market/en/news/commission-andeuropean-regulators-calls-streaming-services-operators-and-users-prevent-network (accessed on 18 November 2020).

Fossati, Luca. 2020. Messe "in onda", ecco Come Fare. Available online: https://www.chiesadimilano.it/news/chiesa-diocesi/messein-onda-ecco-come-fare-339198.html (accessed on 11 November 2020).

Francis. 2013. Apostolic Exhortation “Evangelii Gaudium”. Available online: http://www.vatican.va/content/dam/francesco/ pdf/apost_exhortations/documents/papa-francesco_esortazione-ap_20131124_evangelii-gaudium_en.pdf (accessed on 1 October 2020).

Francis. 2020. Santa Marta. Papa Attenti a Fede “Virtuale”. La Chiesa è con Popolo e con Sacramenti. Available online: https://www. vaticannews.va/it/papa-francesco/messa-santa-marta/2020-04/papa-francesco-messa-santa-marta-coronavirus8.html (accessed on 1 October 2020).

Gawroński, Sławomir, and Ilona Majkowska. 2018. Marketing Communication of the Catholic Church-A Sign of the Times or Profanation of the Sacred? Studia Humana 7: 15-23. [CrossRef]

Giorgi, Alberta. 2019. Mediatized Catholicism-Minority Voices and Religious Authority in the Digital Sphere. Religions $10: 463$. [CrossRef]

Goban-Klas, Tomasz. 2020. Rwacy nurt Mediów. Mediocen—Nowa Faza Mediatyzacji życia Społecznego. Rzeszów-Sosnowiec: Universitas \& Wydawnictwo WSIiZ.

Golan, Oren, and Michele Martini. 2019. Religious live-streaming: Constructing the authentic in real time. Information, Communication $\mathcal{E}$ Society 22: 437-54. [CrossRef]

Gomes, Pedro Gilberto. 2016. Mediatization: A concept, multiple voices. ESSACHESS-Journal for Communication Studies 9: 197-212. Graca, Martin. 2020. Rate of use of social network in Catholic media in Slovakia. European Journal of Science and Theology 16: 113-8.

Gralczyk, Aleksandra. 2020. Social media as an effective pastoral tool. Forum Teologiczne 21: 237-48. [CrossRef] 
Hanas, Zenon. 2013. Internet religijny a religijność internetowa: Eksploracja pola badawczego. In Media w Transformacji. Edited by Aleksandra Gralczyk, Krzysztof Marcyński SAC and Monika Przybysz. Warszawa: Dom Wydawniczy Elipsa, pp. $25-42$.

Helland, Christopher. 2000. Online Religion/Religion Online and Virtual Communities. In Religion on the Internet: Research Prospects and Promises. Edited by Jeffrey K. Hadden and Douglas E. Cowan. Amsterdam, London and New York: JAIPress/Elsevier Science, pp. 205-33.

Hjarvard, Stig. 2008a. The mediatization of religion. A theory of the media as agents of religious change. Nordic Journal of Media Studies 6: 9-26. [CrossRef]

Hjarvard, Stig. 2008b. The Mediatization of Society. A Theory of the Media as Agents of Social and Cultural Change. Nordicom Review 29: 105-34.

Hjarvard, Stig. 2011. The mediatisation of religion: Theorising religion, media and social change. Culture and Religion: An Interdisciplinary Journal 12: 119-35. [CrossRef]

Hofman, Iwona. 2018. Teologia środków społecznego przekazu a paradygmat nauki o mediach. In Teologia Środków Społecznego Przekazu w Naukach o Mediach. Edited by Jerzy Olędzki. Warszawa: Wydawnictwo UKSW, pp. 195-208.

Hoover, Stewart M. 1991. Televangelism Reconsidered. Media Information Australia 60: 17-26. [CrossRef]

Hoover, Stewart. 2011. Media and the imagination of religion in contemporary global culture. European Journal of Cultural Studies 14: 610-25. [CrossRef]

Hutchings, Tim. 2011. Contemporary Religious Community and the Online Church. Information, Communication E Society 14: 1118-35. [CrossRef]

Idziemy.pl/rm. 2020. Edukacja medialna-Nowy przedmiot w polskich seminariach duchownych. Idziemy.pl. March 9. Available online: http://idziemy.pl/kosciol/edukacja-medialna-nowy-przedmiot-w-polskich-seminariach-duchownych/63373 (accessed on 21 November 2020).

Ignatowski, Grzegorz, Łukasz Sułkowski, and Robert Seliga. 2020. Brand Management of Catholic Church in Poland. Religions 11: 607. [CrossRef]

Institute for Catholic Church Statistics. 2018. Annuarium Statisticum Ecclesiae in Polonia AD 2018. Warsaw: Institute for Catholic Church Statistics.

Institute for Catholic Church Statistics. 2020. Annuarium Statisticum Ecclesiae in Polonia AD 2020. Warsaw: Institute for Catholic Church Statistics.

International Theological Commission. 2011. Theology Today: Perspectives, Principles and Criteria. Vatican. Available online: https: //www.vatican.va/roman_curia/congregations/cfaith/cti_documents/rc_cti_doc_20111129_teologia-oggi_en.html (accessed on 3 March 2021).

Jacobs, Stephen. 2007. Virtually Sacred: The Performance of Asynchronous Cyber-Rituals in Online Spaces. Journal of Computer-Mediated Communication 12: 1103-21. [CrossRef]

Jeżak-Śmigielska, Magdalena, Monika Lender-Gołębiowska, and Maciej Makuła. 2018. Teologia mediów i komunikacji jako nowa perspektywa badawcza w naukach o mediach. In Teologia Środków Społecznego Przekazu w Naukach o Mediach. Edited by Jerzy Olędzki. Warszawa: Wydawnictwo UKSW, pp. 171-94.

John Paul II. 1996. Post-Synodal Apostolic Exhortation “Vita Consecrata". Available online: http://www.vatican.va/content/johnpaul-ii/en/apost_exhortations/documents/hf_jp-ii_exh_25031996_vita-consecrata.html (accessed on 3 September 2020).

John Paul II. 1997. Apostolic Exhortation “Catechesi Tradendae". Available online: http://www.vatican.va/content/john-paul-ii/en/ apost_exhortations/documents/hf_jp-ii_exh_16101979_catechesi-tradendae.html (accessed on 1 October 2020).

John Paul II. 1998. Apostolic Letter “Dies Domini” to the Bishops, Clergy and Faithful of the Catholic Church on Keeping the Lord's Day Holy. Available online: http://w2.vatican.va/content/john-paul-ii/en/apost_letters/1998/documents/hf_jp-ii_apl_050719 98_dies-domini.html (accessed on 1 October 2020).

John XXIII. 1961. Encyclical Letter on Christianity and Social Progress Mater Et Magistra. Available online: http:/ /www.vatican.va/ content/john-xxiii/en/encyclicals/documents/hf_j-xxiii_enc_15051961_mater.html (accessed on 1 October 2020).

Jupowicz-Ginalska, Anna, Marcin Szewczyk, Andrzej Kiciński, Barbara Przywara, and Andrzej Adamski. 2021. Dispensation and Liturgy Mediated as an Answer to COVID-19 Restrictions: Empirical Study Based on Polish Online Press Narration. Religions 12: 127. [CrossRef]

Kasowski, Roland. 2018. Edukacja Medialna w Wyższych Seminariach Duchownych w Polsce po roku 1992—Streszczenie Rozprawy Doktorskiej; Electronic Document. Warsaw: Theological Faculty of UKSW. Available online: https://teologia.uksw.edu.pl/sites/default/ files/streszczenie\%20pracy-\%20ks.\%20Ronald\%20Kasowski.pdf (accessed on 21 November 2020).

Konferencja Episkopatu Polski. 2017. Dyrektorium w sprawie Mszy św. transmitowanej przez telewizję. Akta Konferencji Episkopatu Polski 29: 48-55.

Kiciński, Andrzej. 2011. Katecheza osób z Niepetnosprawnościa Intelektualna w Polsce po Soborze Watykańskim II. Lublin: KUL.

Kołodziejska, Marta. 2018. Online Catholic Communities. Community, Authority, and Religious Individualisation. New York: Routledge.

Korpi, Michael F., and Kyong Liong Kim. 1986. The Uses and Effects of Televangelism: A Factorial Model of Support and Contribution. Journal for the Scientific Study of Religion 25: 410-23. [CrossRef]

Królak, Tomasz. 2020. Kościół w czasie pandemii-Nowa era Internetu? Ekai.pl. June 12. Available online: https://ekai.pl/kosciol-wpandemii-nowa-era-internetu (accessed on 21 November 2020).

Krotz, Friedrich. 2007. Mediatisierung. Fallstud. zum Wan. von Komm. Wiesbaden: Springer. 
Krotz, Friedrich. 2009. Mediatization: A concept with which to grasp media and societal change. In Mediatization: Concept, Changes, Consequences. Edited by Knut Lundby. New York: Peter Lang, pp. 21-40.

Kurdupski, Michał. 2020. Rekordy oglądalności mszy świętych w telewizji. Wirtualnemedia.pl. April 15. Available online: https://www. wirtualnemedia.pl/artykul/duzy-wzrost-ogladalnosci-mszy-swietych-koronawirus-analiza (accessed on 21 November 2020).

Leśniczak, Rafał. 2018. Teologia środków społecznego przekazu i nauki o mediach jako dwie perspektywy badań wizerunku medialnego przywódców religijnych Kościoła katolickiego-Kilka uwag do dyskusji. In Teologia Środków Społecznego Przekazu w Naukach o Mediach. Edited by Jerzy Olędzki. Warszawa: Wydawnictwo UKSW, pp. 339-56.

Leśniczak, Rafał. 2019. Mediatization of Institutional Communication of the Catholic Church. Reflections on the Margins of the Migration Crisis. Studia Medioznawcze 3: 237-46. [CrossRef]

Leśniczak, Rafał. 2020. Komunikowanie polskich biskupów w kontekście kryzysu pedofilii. W trosce o zasady skutecznej komunikacji. Kultura-Media-Teologia 42: 53-73. [CrossRef]

Liljequist, Fredrik. 2016. Live-Streaming as a Marketing Channel in the Swedish Music Industry. Stockholm: KTH Royal Institute of Technology, Available online: https:/ / www.diva-portal.org/smash/get/diva2:942217/FULLTEXT01.pdf (accessed on 20 June 2020).

Lundby, Knut. 2009. Mediatization: Concept, Changes, Consequences. Bern: Peter Lang.

Lundby, Knut. 2011. Patterns of Belonging in Online/Offline Interfaces of Religion. Information, Communication E Society 14: 1219-35. [CrossRef]

Lundby, Knut. 2014. Mediatization of Communication. 21 vols. Berlin: Walter de Gruyter GmbH \& Co KG.

Magnin, Thierry. 2013. Scientists and Theologians in Front of the Mystery. In Transdisciplinary Theory E Practice. Edited by Basarab Nicolescu and Atila Ertas. Lubbock: The Atlas, pp. 29-58.

Makuła, Maciej. 2019. Transmisje Mszy świętych w live-streamingu w Internecie. analiza możliwości, postulaty i propozycje. Seminare 1: 37-49. [CrossRef]

Martino, Luis Mauro Sá. 2020. Mediatization of Religion: Three Dimensions from a Latin American/Brazilian Perspective. Religions 11: 482. [CrossRef]

Mette, Norbert. 2005. Einführung in die Katholische Praktische Theologie. Darmstadt: Wbg Academic in Wissenschaftliche Buchgesellschaft (WBG).

Midali, Mario. 2011. Teologia Pratica. 5. Per un'attuale Configurazione Scientifica. Roma: Las.

Mikuláš, Peter, and Ol'ga Chalányová. 2017. Celebritization of religious leaders in contemporary culture. European Journal of Science and Theology 13: 43-52.

Mishol-Shauli, Nakhi, and Oran Golan. 2019. Mediatizing the Holy Community-Ultra-Orthodoxy Negotiation and Presentation on Public Social-Media. Religions 10: 438. [CrossRef]

Misztal, Wojciech. 2020. Powszechne oddziaływanie: Przekaz medialny i pierwsze papieskie orędzie radiowe. Kultura-Media-Teologia 42: 91-108. [CrossRef]

NB. 2020. Telewizje kablowe oferują transmisje mszy świętych z lokalnych parafii. Wirtualnemedia.pl. March 25. Available online: https:/ / www.wirtualnemedia.pl/artykul/msza-swieta-w-telewizji-gdzie-ogladac-i-sluchac-lista-miast (accessed on 21 November 2020).

Nguyen, Minh Hao, Jonathan Gruber, Jaelle Fuchs, Will Marler, Amanda Hunsaker, and Eszter Hargittai. 2020. Changes in Digital Communication during the COVID-19 Global Pandemic: Implications for Digital Inequality and Future Research. Social Media + Society 6: 1-6. [CrossRef]

Parish, Helen. 2020. The Absence of Presence and the Presence of Absence: Social Distancing, Sacraments, and the Virtual Religious Community during the COVID-19 Pandemic. Religions 11: 276. [CrossRef]

Pastwa, Rafał. 2020. Komunikowanie religijne na przykładzie Kościoła katolickiego w Polsce z uwzględnieniem kontekstu pandemii koronawirusa. Kultura-Media-Teologia 41: 38-60. [CrossRef]

Pires, Karine, and Gwendal Simon. 2015. YouTube Live and Twitch: A Tour of User-Generated Live-streaming Systems. Paper presented at ACM Press the 6th ACM Multimedia Systems Conference, Portland, OR, USA, March 18-20; pp. 225-30. [CrossRef]

Pisarek, Walery. 2008. Wstęp do Nauki o Komunikowaniu. Warszawa: PWN.

Pope Paul VI. 1965. Pastoral Constitution on the Church in the Modern World Gaudium et spes; Vatican City: Libreria Editrice Vaticana, Second Vatican Council. Available online: http://www.vatican.va/archive/hist_councils/ii_vatican_council/documents/vat-ii_ cons_19651207_gaudium-et-spes_en.html (accessed on 1 October 2020).

Radej, Maciej. 2020. “Mira sane ope Marconiana”. Pierwsze radiowe transmisje mszy świętych. Kultura-Media-Teologia 43: 88-101.

Reimann, Ralf Peter. 2017. "Uncharted Territories": The Challenges of Digitalization and Social Media for Church and Society. The Ecumenical Review 69: 67-79. [CrossRef]

Robak, Marek. 2018. Badania stron internetowych diecezji w Polsce metoda WebScan. In Teologia Środków Społecznego Przekazu w Naukach o Mediach. Edited by Jerzy Olędzki. Warszawa: Wydawnictwo UKSW, pp. 359-89.

Ruether, Traci. 2019. Live-streaming vs. Traditional Live Broadcasting: What's the Difference. Available online: https://www.wowza. $\mathrm{com} / \mathrm{blog} /$ streaming-vs-cable-satellite-broadcasting (accessed on 6 August 2020).

Sadłoń, Wojciech. 2013. Społeczny wymiar parafii wiejskiej w Polsce na podstawie badań statystycznych. Trzeci Sektor 29 : 37-46.

Sadłoń, Wojciech. 2018. Religijność w strukturze polskiego społeczeństwa. Wstęp do zagadnienia. Warszawskie Studia Pastoralne 13: 183-95. 
Sands, Justin. 2018. Introducing Cardinal Cardijn's See-Judge-Act as an Interdisciplinary Method to Move Theory into Practice. Religions 9: 129. [CrossRef]

Serwis RP. 2020. Wprowadzamy nowe zasady bezpieczeństwa w związku z koronawirusem. March 24. Available online: https: / / www.gov.pl/web/koronawirus/wprowadzamy-nowe-zasady-bezpieczenstwa-w-zwiazku-z-koronawirusem (accessed on 17 April 2020).

Seweryniak, Henryk. 2010. Teologie na "progu domu". Kultura-Media-Teologia 1: 10-23. [CrossRef]

Sheppard, Phil, and Graham Walter, eds. 1999. Telepresence. Dordrecht: Springer Science+Business Media.

Sierocki, Radosław. 2018. Praktykowanie Religii w Nowych Mediach. Katolicka Przestrzeń Facebooka. Torun: Wydawnictwo Adam Marszałek.

Skačan, Juraj. 2017. On virtual reality of religion. European Journal of Science and Theology 13: 15-23.

Soukup, Paul. 2019. Some past meetings of communication, theology, and media theology. Kultura-Media-Teologia 38: 25-46. [CrossRef] Stacja7/redakcja. 2020. Msza święta w domu. Jak najlepiej ja przeżyć? Stacja7.pl. March 21. Available online: https://stacja7.pl/stylzycia/msza-swieta-w-domu-jak-najlepiej-ja-przezyc/ (accessed on 17 November 2020).

Statistics Poland. 2020a. Administrative Division of Poland. Available online: https://stat.gov.pl/en/regional-statistics/classificationof-territorial-units/administrative-division-of-poland/ (accessed on 23 June 2020).

Statistics Poland. 2020b. Types of Gminas and Urban and Rural Areas. Available online: https://stat.gov.pl/en/regional-statistics/ classification-of-territorial-units/administrative-division-of-poland/types-of-gminas-and-urban-and-rural-areas/ (accessed on 23 June 2020).

Sułkowski, Łukasz. 2020. Covid-19 Pandemic; Recession, Virtual Revolution Leading to De-globalization? Journal of Intercultural Management 1: 1-11. [CrossRef]

Sulkowski, Lukasz, and Grzegorz Ignatowski. 2020. Impact of COVID-19 Pandemic on Organization of Religious Behaviour in Different Christian Denominations in Poland. Religions 11: 254. [CrossRef]

Święciński, Bartosz. 2020. Rzecznik KEP: Obecność Kościoła w mediach społecznościowych jest niezbędna. Radio Warszawa. September 6. Available online: https: / / radiowarszawa.com.pl/rzecznik-kep-obecnosc-kosciola-w-mediach-spolecznosciowychjest-niezbedna/ (accessed on 21 November 2020).

Szczepaniak, Maciej. 2012. Radiowa transmisja mszy św. z Kongresu Eucharystycznego w Dublinie. Przełom w recepcji transmisji radiowych w praktyce eklezjalnej. Kultura-Media-Teologia 9: 8-19. [CrossRef]

Szczepaniak, Maciej. 2018. Wideosłowa-o przepowiadaniu w formie audiowizualnej. Polonia Sacra 22: 79-95. [CrossRef]

Szocik, Konrad, and Joanna Wisła-Płonka. 2018. Moral Neutrality of Religion in the Light of Conflicts and Violence in Mediatized World. Social Communication 4: 76-88. [CrossRef]

The Church of England. 2020. COVID-19 Livestreaming Worship. Available online: https:/ /www.churchofengland.org/sites/default/ files/2020-11/COVID\%2019\%20Livestreaming\%20Worship\%20v1.0_1.pdf (accessed on 25 November 2020).

The Conference of Major Superiors of Women Religious Orders. 2019. Ewangelizacja przez media. Zestawienie statystyczne zaangażowania sióstr w duszpasterstwo stan na 01.01.2019 r. Available online: https:// zakony-zenskie.pl/wp-content/uploads/ 2020/05/Duszpasterstwo_2019.01.01-.pdf (accessed on 10 December 2020).

The Council of Ministers of the Republic of Poland. 2020. Narodowy Plan Szerokopasmowy. Załacznik do uchwały nr 27/2020 Rady Ministrów z dnia 10 marca 2020. Available online: https:/ / mc.bip.gov.pl/fobjects / download/776267/aktualizacja-narodowegoplanu-szerokopasmowego-przyjeta-przez-rade-ministrow-w-dniu-10-marca-2020-r-pdf.html (accessed on 2 January 2021).

Tudor, Mihaela Alexandraand, and Stefan Bratosin. 2018. Croire en la Technologie: Médiatisation du Futur et Futur de la Médiatisation. Iarsic: Les Arcs.

Tudor, Mihaela Alexandraand, and Stefan Bratosin. 2020. French Media Representations towards Sustainability: Education and Information through Mythical-Religious References. Sustainability 12: 2095. [CrossRef]

Tworzydło, Dariusz, Sławomir Gawroński, and Marek Zajic. 2020. Catholic Church in Poland in the Face of Paedophilia. Analysis of Image Actions. European Journal of Science and Theology 16: 157-72.

Wieczorek, Bartosz. 2012. Wokół religii mediów. Kultura-Media-Teologia 11: 18-31. [CrossRef]

Wielgosz, Zbigniew. 2020. Jak zamienić dom w domowy Kościół? Jak przeżyć w nim Mszę św.? Jak przygotować mały ołtarzyk? Wiara.pl. March 13. Available online: https:/ / kosciol.wiara.pl/doc/6215631.Jak-zamienic-dom-w-domowy-Kosciol-Jak-przezycw-nim-Msze-sw-Jak (accessed on 17 November 2020).

Xiong, Jianhui (Jane), Nazila Isgandarova, and Amy Elizabeth Panton. 2020. annuarCOVID-19 Demands Theological Reflection: Buddhist, Muslim, and Christian Perspectives on the Present Pandemic. International Journal of Practical Theology 24: 5-28. [CrossRef]

Young, William. 2019. Reverend Robot: Automation and Clergy. Zygon ${ }^{\circledR}$ 54: 479-500. [CrossRef]

Young Christian Workers. 2020. The Method of See, Judge, Act, Review. Available online: https: / ycw.ie/resources/see-judge-actresources-2 (accessed on 22 November 2020).

Zdaniewicz, Witold. 2001. Dane Statystyczne Dotyczace Diecezji. Available online: https://opoka.org.pl/biblioteka/V/trans/msze/ stat2.html (accessed on 4 November 2020).

Zimmermann, Carol. 2020. Parishes step up their social media efforts by posting online Masses. Crux. March 26. Available online: https: / / cruxnow.com/church-in-the-usa/2020/03/parishes-step-up-their-social-media-efforts-by-posting-online-masses / (accessed on 25 November 2020). 